\title{
Génesis de los estudios sobre música colonial hispanoamericana: un esbozo historiográfico
}

\author{
Juliana Pérez González \\ Universidad Nacional de Colombia \\ julianabe@gmail.com
}

\begin{abstract}
Resumen $^{1}$
En este artículo se hace un recorrido por los escritos más representativos sobre música colonial de hispanoamérica publicados entre 1876 y 1976. El tema ha despertado interés desde finales del siglo XIX en músicos con poca formación en ciencias humanas y, a partir de los años sesenta, en la musicología. A lo largo del ensayo se analiza la forma en que autores en diferentes países y momentos clasificaron la música colonial, y los temas más trabajados, como la música indígena, de los esclavos, en la catedral, en las misiones, la música doméstica y los instrumentos utilizados en su interpretación. El objetivo general es mostrar cómo los diferentes matices puestos en los temas y la clasificación están relacionados con el momento que vivió cada autor y con las herramientas documentales y mentales que su tiempo le ofreció.
\end{abstract}

Palabras clave: MÚSICA COLONIAL HISPANOAMERICANA, ENSAYO HISTORIOGRÁFICO.

\begin{abstract}
This article examines the most representative texts on Hispanic American colonial music published between 1876 and 1976. Since the end of the $19^{\text {th }}$ century, the topic has generated interest in musicians with little training in the human sciences and, from the 1960s onwards, among musicologists. The essay analyzes the ways in which authors in different countries classified colonial music, and the topics that were studied such as indigenous, slave, cathedral, mission, and domestic music as well as musical instruments. The general objective is to show how the different emphases placed on the topics and

1 Agradezco a todas las personas que colaboraron en este artículo, principalmente al Instituto Colombiano de Antropología e Historia por la fe que puso en él. Doy gracias a quienes aportaron con sus observaciones, ideas y ayuda técnica, como también a quienes con desprendimiento y hospitalidad me colaboraron en la búsqueda bibliográfica.
\end{abstract}


the classifications are related to the social and historical milieu of each author, and the documentary sources and mental tools the period offered.

Key words: HISPANIC AMERICAN COLONIAL MUSIC, HISTORIOGRAPHICAL OUTLINE

\section{Introducción}

Quien en los últimos cinco años se haya detenido en la sección de “música clásica” de una tienda de discos, muy seguramente se ha topado con algún costoso CD que se anuncie como Música Colonial Hispanoamericana²; entonces ese alguien habrá visto una muestra de la creciente difusión e interés -acentuados en la última década- que ha generado este tipo de repertorio en todo el mundo. Otro indicio de este auge es la gran cantidad de grupos musicales que se han especializado en la reconstrucción e interpretación de la música colonial hispanoamericana y que buscan revivir las sonoridades que ella tuvo, tocando en réplicas de instrumentos de la época, aplicando las técnicas que la interpretación exige y usando escenarios como catedrales y capillas. Además de llamar la atención de empresarios, músicos y melómanos, la música del período colonial también ha sido objeto de estudio de la musicología ${ }^{3}$, con espacios representativos especializados, como el Festival Internacional de Música Renacentista y Barroca Americana “Misiones de Chiquitos”, que se realiza con el aporte de organismos internacionales, o la apertura del posgrado en música colonial latinoamericana ofrecido por la Universidad Católica de Argentina, entre otros.

Consideramos que en el entusiasmo por la música colonial hispanoamericana han influido varios factores, entre los que identificamos tres: el movimiento early music o música antigua, la llegada de la musicología a Hispanoamérica y la vigencia que han adquirido los estudios de música colonial en relación con el presente. El movimiento de la early music tomó fuerza en Europa hacia la década de 1950, preocupado por la reconstrucción histórica de repertorios musicales de los siglos XVI, XVII y XVIII";

2 Actualmente hay sellos discográficos especializados en este repertorio, como por ejemplo K617, de Francia, o Urtext, de México.

3 El término musicología ha sido definido de diferentes maneras a través del tiempo, pero, en general, podemos decir que es el campo del conocimiento que toma a la música como un fenómeno físico, psicológico, estético y cultural. En el siglo XVIII, el historiador alemán Johann Nikolaus Forkel propuso la división entre musicología histórica, dedicada a estudiar la música en el tiempo, y musicología sistemática, encargada de su teoría y práctica. Hoy en día esta división tiene alguna vigencia pero está siendo revaluada por los nuevos rumbos que ha tomado esta disciplina. Véanse: Frank Harrison, Mantle Hodd and Claude Palisca, Musicology (New Jersey: The Princeton Studies: Humanistic Scholarship in America, 1963); Joseph Kerman, Contemplating Music. Challenges to Musicology (Cambridge: Harvard University Press, 1985); Jacques Chailley, Compendio de musicología, 2 ed. (1958; reimpresión, Madrid: Alianza, 1991); Vicent Duckles y otros, "Musicology", en The New Grove Dictionary of Music and Musicians, ed. Stanley Sadie (New York: MacMillan, 2001). Obtenido en la red mundial el 16 de enero de 2004, 4:30 horas. http://www.grovemusic.com

4 Véase Harry Haskell, The early music revival: a history (Mineola, New York: Dover, 1996). 
este movimiento se volcó sobre América Latina en el siglo XX hacia los años sesenta, tal vez motivado por la estética exótica europea y encontró eco en la situación por la que pasaban los estudios de historia musical en nuestro continente.

Para entender qué sucedía por esos años respecto a la situación de la historia de la música hispanoamericana debemos echarle un vistazo al desarrollo de la musicología, pues el estudio de la música del período colonial ha estado más cercano a ella que a la historia. Como el auge actual hace parte del desarrollo que ha tenido la musicología en nuestro continente, es pertinente hacer una síntesis de su proceso desde mediados del siglo XIX, cuando surgió 5 .

Los primeros escritos de corte histórico-musical se publicaron en secciones de periódicos para el hogar y poco después fueron reelaborados como folletos bajo títulos que incluían los calificativos “esbozo”, “apuntes” o "nociones” para la historia de la música. A medida que entraba el siglo XX, con la presencia del nacionalismo, la producción de historias musicales se extendió por toda Hispanoamérica y se publicaron grandes textos pioneros que intentaron escribir la historia de la música de sus países desde sus orígenes hasta el momento de su elaboración. En la década de 1960 los enfoques variaron y se empezaron a dejar de lado los proyectos titánicos anteriores, remplazándolos por la especialización en temas más puntuales; este giro fue causado por la llegada de la musicología y, con ella, de nuevos parámetros a los países de habla hispana ${ }^{6}$. En la actualidad se pueden identificar varios campos de especialización que abarcan estudios sobre la música popular, la etnomusicología, la organología y, por supuesto, la música colonial, entre otros varios. En resumen, podemos decir que la historia de la música empezó produciendo narraciones y discursos, es decir, textos escritos para ser leídos. Y más tarde, cuando llegó la musicología, la investigación generó otro tipo de resultados como la edición de partituras y la grabación del repertorio; por lo tanto, esta nueva etapa construyó un nuevo tipo de textos: textos para ser interpretados y escuchados.

5 No encontramos trabajos que profundicen en la historia de la musicología en Hispanoamérica; sin embargo, dan algunas luces los artículos de Leopoldo Hurtado, “Apuntes sobre historiografía musical”, Revista Musical Chilena (Santiago), 41 (otoño 1951): 17-36, y Samuel Claro, "Los grandes gestores de la musicología latinoamericana contemporánea”, Revista Musical de Venezuela (Caracas) 12, núm. 30-31 (enero-diciembre 1992): 65-81. Por nuestra parte, consideramos que la historiografía musical se inició como tal a mediados del siglo XIX, representada por los trabajos que tuvieron la intención explícita de hacer un relato histórico-musical, pues aunque describir la música ha sido un interés común tanto de historiadores del siglo XIX y XX como de cronistas, estos últimos mencionaron lo musical como parte del paisaje y no como tema capital. Haciendo esta distinción, ubicamos entonces el inicio de la historiografía a mediados del siglo XIX. También, Juliana Pérez, Las historias de la música en Hispanoamérica: un balance historiográfico (1876-2000) (Tesis de licenciatura, Universidad Nacional de Colombia, Bogotá, 2004).

${ }_{6}$ Entre estos nuevos parámetros es notorio el énfasis que la musicología puso en el material musical, introduciéndolo a sus análisis como parte fundamental. 
Y, por último, el estudio de la música del período de dominación española ha atraído la mirada de diferentes musicólogos y etnomusicólogos, que identifican cierto tipo de permanencias de la cultura musical colonial en las manifestaciones musicales actuales. Por ejemplo: de esta manera se han explicado tradiciones campesinas de construcción de instrumentos que han retenido técnicas coloniales ${ }^{7}$ y se ha visto cómo la música indígena o tradicional de las zonas donde se establecieron misiones jesuitas tiene características particulares relacionadas con la política cultural impartida por esta orden en el siglo XVII ${ }^{8}$.

En este artículo fijaremos nuestra atención en la producción que ha generado el estudio de la música colonial hispanoamericana ${ }^{9}$ principalmente en los cien años comprendidos entre la publicación de lo que hemos considerado la primera historia de la música, en 1876, hasta 1976, un año después de haber sido publicada la Antología de música latinoamericana hecha por Robert Stevenson, fecha en que este autor publicó la trascripción de la primera ópera colonial y el primer escrito de corte historiográfico sobre el estudio de la música de este período. Lo anterior significa que este balance se centrará en los primeros productos de la historiografía hispanoamericana y hará breves referencias a lo que hemos considerado el auge de los estudios musicológicos a partir de los años setenta, dejando para futuros trabajos el análisis y estudio minucioso de esta producción.

Hemos tomado tres tipos de textos en los que se ha plasmado la historia de la música colonial: las historias generales de la música, los trabajos monográficos y algunas ediciones de partituras y catálogos de archivos coloniales. Aunque nuestro propósito inicial fue estudiar la historiografía musical hispanoamericana, la ubicación del material esparcido por el continente nos redujo los límites geográficos y dejó por fuera gran parte de Centroamérica y del Caribe hispanoparlante, imposibilitándonos el acceso a

7 Por ejemplo: Egberto Bermúdez, "Instrumentos musicales latinoamericanos del período colonial. El arpa de Tópaga (Colombia) y la vihuela de la Iglesia de la Compañía de Jesús de Quito (Ecuador)”, Revista Musical de Venezuela (Caracas), 12, núm. 30-31 (enero-diciembre1992): 155-162; La música en el arte colonial de Colombia (Bogotá: Fundación de Música, 1994).

8 Entre otros ejemplos: Irma Ruiz, "Herederos de la colonización jesuítica: el caso de los chiquitos”, Revista Musical de Venezuela (Caracas), 16, núm. 34 (mayo-agosto 1997): 7-20.

9 Hemos optado por no incluir la producción sobre Brasil por la difícil consecución del material en nuestro medio hispano y por la gran cantidad de estudios que sobre la materia ha tenido este país. Sin embargo, hay que resaltar que los problemas y enfoques de la historiografía musical brasileña son interesantes y ameritan una revisión posterior. Véase: Alexandre Antonio Bispo, “Tendencias e perspectivas da musicologia no Brasil”, Boletin da Sociedade Brasileira de Musicología (Sao Paulo), 1, núm. 1 (1983): 13-51. 
producción referenciada, como el caso de Puerto Rico, en donde se viene trabajando la historia musical desde el siglo XIX ${ }^{10}$.

En la década de 1960 se hizo notorio el empuje que desde la anterior venían teniendo los estudios sobre música colonial. Este auge es hoy reconocible en el número elevado de artículos y libros publicados en comparación con lo anteriormente escrito; además, es significativo el reconocimiento del tema que hizo en 1962 la Revista Musical Chilena -la publicación especializada hispanoamericana más antigua y una de las de mayor prestigio- dedicando el número 81-82 a los trabajos de vanguardia de grandes figuras como Lauro Ayestarán, José Antonio Calcaño, Vicente Gesualdo, Pablo Hernández Balaguer, Andrés Sas, Robert Stevenson y Carlos Vega, dedicados a lo colonial ${ }^{11}$.

No obstante, este era un esquema que ya venían tratando algunos autores de manera aislada y que se perfilaba como tema monográfico desde 1929, cuando en el libro Nuestra música instrumental el sacerdote jesuita Pedro Grenon se propuso desmentir las afirmaciones sobre la "vida triste y prosaica" de la colonia que autores anteriores "generalizan sin base histórica ni documental" ${ }^{12}$. Muy seguramente, el padre Grenon hacía alusión a textos como las historias generales de la música hispanoamericana que ilustraban el período colonial de manera rápida con el fin de dar a sus lectores una visión global de la actividad musical, desde sus orígenes hasta el presente. Estas historias de la música que empezaron a aparecer a mediados del

10 Véase Annie Figueroa de Thompson, Bibliografía anotada sobre la música en Puerto Rico (Barcelona: Instituto de Cultura Puertorriqueña San Juan de Puerto Rico, 1977).

11 Véanse Revista Musical Chilena (Santiago), 16, núm. 81-82 (julio-diciembre 1962); Lauro Ayestarán, “Doménico Zipoli y el barroco musical sudamericano”, 94-125; José Antonio Calcaño, "Música colonial venezolana”, 195-200; Pablo Hernández Balaguer, "Panorama de la música colonial cubana”, 201-208; Andrés Sas, "La vida musical en la Catedral de Lima durante la Colonia”, 8-53; Robert Stevenson, "La música colonial en Colombia”, 153-171; “La música en Quito”, 172-194, y Carlos Vega “Un códice peruano colonial del siglo XVII”, 54-93

12 Pedro Grenon, Nuestra primera música instrumental: datos históricos (Buenos Aires: Librería "La Cotizadora Económica", 1929), 1. Otros trabajos de este período centrados en el mundo colonial son: Carlos Vega, La música de un códice colonial del siglo XVII (Buenos Aires: Universidad de Buenos Aires, 1931); Gabriel Saldivar, Historia de la música en México: épocas precortesiana y colonial (México: Cultura, 1934); Miguel Bernal Jiménez, El archivo musical del Colegio de Santa Rosa de Santa María Valladolid (Morelia: Universidad Michoacana de San Nicolás, 1939); Lauro Ayestarán, Doménico Zipoli. El gran compositor y organista romano del 1700 en el Río de la Plata (Montevideo: Impresora Uruguaya, 1941); "Fuentes para el estudio de la música colonial Uruguaya”, Revista de la Facultad de Humanidades y Ciencias (Montevideo), 1, núm. 1 (1947): 1- 57; Juan Bautista Plaza, Archivo de música colonial venezolana (Montevideo: Cooperativa Interamericana de Compositores, 1943); Guillermo Furlong, Músicos argentinos durante la dominación hispánica (Buenos Aires: Haurpes, 1945); Lota Spell, "Music in the Cathedral of Mexico in the Sixteenth Century", Hispanic American Historical Review (Durham), 26, núm. 3 (agosto 1946): 294-319. 
siglo XIX fueron los primeros escritos que hicieron referencia a la música colonial y, aun después de iniciados los trabajos particulares, han sido un punto de referencia importante para conocer la música de este período ${ }^{13}$.

\section{Autores y disciplinas}

En cuanto a la formación de las personas que de una u otra forma han trabajado lo colonial, cabe destacar que desde los inicios de la historiografía musical hispanoamericana ha predominado la participación de músicos y compositores, quienes a lo largo de sus vidas se adentraron en la investigación histórica guiados más por su intuición que por una formación académica en la disciplina; sin embargo, desde mediados del siglo XX la historiografía musical ha venido siendo desarrollada por musicólogos, que a su vez vienen de una formación básica en música y han entrado en contacto con las ciencias humanas a lo largo de su formación musicológica.

En relación con el tema de la formación en investigación musical, sería interesante examinar los planes de estudio de los posgrados en musicología de universidades estadounidenses e hispanoamericanas y demás instituciones donde se hayan formado los musicólogos especialistas en Hispanoamérica, en busca de un mejor entendimiento de las visiones sobre el mundo colonial construidas por los autores, las cuales se encuentran alejadas de los planteamientos de la historia colonial en general.

El problema de la formación de los investigadores es importante porque de ella dependió muchas veces la manera de tratar diferentes problemas, como la pregunta implíci-

13 Entre las historias generales de la música podemos mencionar: Juan Agustín Guerrero Toro, La música ecuatoriana desde su origen hasta 1875, 2 ed., (1876; reimpresión, Fuentes y documentos para la historia de la música del Ecuador, Quito: Banco Central del Ecuador, 1984); José Sáenz Poggio, "Historia de la música guatemalteca desde la monarquía española hasta fines del año 1877”, 2 ed., Anales de la Sociedad de Geografía e Historia de Guatemala (Guatemala), 22, núm. 1-2 (marzo-junio 1947): 1-80; Juan Crisóstomo Osorio, "Breves apuntamientos para la historia de la música en Colombia”, Repertorio Colombiano (Bogotá), 3, núm. 15 (1879): 162-166; Ramón de la Plaza, Ensayos sobre el arte en Venezuela (facsímil 1883; reimpresión, Caracas: Imprenta al Vapor de "La Opinión Nacional”, 1983); Segundo Luis Moreno, “La música en el Ecuador”, en El Ecuador en 100 años de independencia, vol. 2 (Quito: Escuela Tipográfica Salesiana; Imprenta de Artes y Oficios, 1930); Andrés Martínez Montoya, "Reseña histórica sobre la música en Colombia desde la época de la Colonia hasta la fundación de la Academia Nacional de Música”, Anuario de la Academia Colombiana de Bellas Artes, 1932; Víctor Miguel Díaz, Las bellas artes en Guatemala (Guatemala: Tipografía Nacional, 1934); José Ignacio Perdomo Escobar, “Esbozo histórico sobre la música colombiana”, Boletín Latinoamericano de Música (Bogotá), 4 (1938): 387-560; Eugenio Pereira Salas, Los orígenes del arte musical en Chile (Santiago: Imprenta Universitaria, 1941); Alejo Carpentier, La música en Cuba (México: Fondo de Cultura Económica, 1946); Robert Stevenson, Music in Mexico. A Historical Survey. (Nueva York: Thomas y Crowell, 1952); Lauro Ayestarán, La música en el Uruguay (Montevideo: Servicio Oficial de Difusión Radio Eléctrica, 1953); Juan Max Boettner, Música y músicos del Paraguay (Asunción: Autores Paraguayos Asociados, 1957); Vicente Gesualdo, Historia de la música en la Argentina, 3 vols. (Buenos Aires: Beta S.R.L., 1961); Andrés Pardo Tovar, "La cultura musical en Colombia” en Historia Extensa de Colombia, vol. 10, t. 6. (Bogotá: Lerner, 1966); y Samuel Claro y Jorge Urrutia Blondel, Historia de la música en Chile (Santiago: Orbe, 1973). 
ta sobre por qué estudiar la música colonial, además que mostró matices en su posición frente a problemas tácitos y comunes a toda la historiografía musical, como resolver la dualidad entre hacer historia de la música o de los músicos, y la cuestión de otorgar o no un valor estético al material musical. La formación de los autores también intervino en aspectos más elementales, como el grado de rigor en la citación de la documentación usada.

\section{El interés por la música colonial}

Diferentes fueron los motivos por los que se estudió la música colonial entre 1876 y 1976. Las historias generales frecuentemente inician con un capítulo dedicado a la actividad musical anterior a las guerras de independencia, que titulan como música bajo la dominación española, música en los siglos XVI, XVII y XVIII o música colonial ${ }^{14}$; también es habitual que se dedique a este tiempo un porcentaje relativamente pequeño en número de páginas, comparado con el espacio y profundidad que tienen los capítulos sobre los siglos XIX y XX. A este tratamiento del tema colonial lo hemos llamado "paso obligado", pues la idea de hacer historias generales de la música desde los orígenes hasta el presente obligó a los autores a revisar qué sucedió durante la colonia. Otro factor importante en este "paso obligado" fue la idea reinante en la primera mitad del XX sobre la necesidad de buscar los orígenes para poder explicar los desarrollos posteriores; esto indujo a los autores a revisar todo lo anterior a las guerras de independencia en busca de los inicios de lo que fue y venía siendo la música de los siglos XIX y XX, en la cual estaban interesados realmente.

Estas historias generales de la música fueron motivadas por dos momentos particulares que vivió la actividad musical hispanoamericana. Uno, a finales del siglo XVIII e inicios del XIX, que se puede resumir en el asentamiento de la estética musical italiana y la posterior institucionalización de la música con la apertura de sociedades filarmónicas y conservatorios influidos por este nuevo estilo. El otro momento importante al que nos referiremos se dio con fuerza en la transición al siglo XX. Se trata del nacionalismo musical, que influyó en los discursos en torno a la música y buscó concretarse en las composiciones y el repertorio de cada país ${ }^{15}$.

14 Existen algunas excepciones, como el libro del músico Rafael Vásquez Historia de la música en Guatemala (Guatemala: Tipografía Nacional, 1950) donde el autor inicia directamente con el siglo XIX, o el caso de José Díaz Gainza Historia musical de Bolivia, 2 ed., (1962; reimpresión, La Paz: Puerta del Sol, 1977) dedicada exclusivamente a la música prehispánica. La historia de la música de Eugenio Pereira Salas Historia de la música en Chile (1850-1900) (Santiago: Universidad de Chile, 1957) y la de Segundo Luis Moreno Historia de la música en el Ecuador (Quito: Casa de la Cultura Ecuatoriana, 1972) tampoco incluyen el período colonial y están dedicadas solo a los siglos XIX y $\mathrm{XX}$, a pesar de que estos dos autores ya habían trabajado la época en publicaciones anteriores.

15 Véase: Gerard Behague, La música en América Latina. Una introducción (Caracas: Monte Ávila, 1983). 
El texto del ecuatoriano Agustín Guerrero Toro, publicado en 1876, puede ser producto del enfrentamiento entre la estética italiana y la tradición renacentista y barroca española anterior, pues el acercamiento al mundo colonial que hace este autor parece estar impulsado por el deseo de legitimar la práctica musical de sus contemporáneos en detrimento de la anterior. Guerrero diferencia entre el "sistema antiguo" (seguramente renacentista) y la música moderna (seguramente italiana) como dos prácticas opuestas ${ }^{16}$, y teje su texto desde la comparación entre la pobreza musical colonial y el rico uso decimonónico que, a su vez, sustenta con la labor de las escuelas de música y el conservatorio. La postura del autor a favor de la función del conservatorio se hace más relevante al saber que Guerrero Toro fue director de esta institución en $1871^{17}$.

En segundo lugar, el nacionalismo musical también motivó la búsqueda de los orígenes nacionales en el pasado y particularmente en el período colonial; se consideraba que allí se encontrarían elementos musicales que les permitiría a los compositores construir una música que identificara y distinguiera a la nación ${ }^{18}$. Ejemplos de esta afanosa búsqueda son La música en Cuba (1946) de Alejo Carpentier, quien perteneció al movimiento intelectual nacionalista cubano, representado por autores como Fernando Ortiz -amigo personal del escritor-. Carpentier construyó su relato del período colonial resaltando el importante aporte del elemento negro y negando otras influencias, para así sustentar el discurso político-cultural afrocubano en boga. De la misma manera, otros autores como Gabriel Saldivar, en México ${ }^{19}$; Juan Crisóstomo Osorio, en Colombia $^{20}$, y Luis Segundo Moreno, en Ecuador, revisaron el período con los anteojos del nacionalismo musical de sus países.

También motivó el estudio de la música colonial el hallazgo de alguna que otra fuente documental rica en datos y el conocimiento de archivos que mostraron la existencia de una actividad colonial musical prolífica. Tales hallazgos ocasionaron que se dejara de estudiar el período colonial como un capítulo más de la historia musical, y así lo colonial pasó a ser considerado como tema monográfico. Estos son los casos de obras

16 Guerrero, La música ecuatoriana, 9.

17 Guerrero Toro escribió su libro para exaltar la labor del gobierno ecuatoriano que apoyó la fundación del Conservatorio de Música y darle legitimidad e importancia a este hecho por medio del relato histórico. Por otra parte, este mismo tipo de estímulo ocasionó que Andrés Martínez Montoya escribiera el artículo "Reseña histórica sobre la música en Colombia”, 9, con el fin de justificar y engalanar con la historia a la Academia Nacional de Música en la cual él participó activamente: “y llegamos al acontecimiento de mayor trascendencia en los anales de nuestra historia musical: la fundación de la Academia Nacional de Música”.

18 Para este momento, el reproche y menosprecio anteriormente creados por los discursos independentistas frente al período de dominación hispánica habían cedido, y en el momento algunas corrientes hacían una nueva lectura que permitía sustentar la identidad nacional en ese pasado ahora lejano.

19 “[...] y se ha llegado en antecedentes hasta la mitad del siglo XVIII, pareciéndonos reciente, demasiado reciente el tiempo que se ha fijado para la consolidación de la música y cultura musical” Saldivar, Historia de la música en México, prólogo. 
como La música de un códice colonial del siglo XVII (1931), de Carlos Vega, y La música en la Catedral de Lima durante el Virreinato (1972), de Andrés Sas. En cuanto al origen de su trabajo sobre la música colonial, Sas decía:

[...] circunstancias imprevistas [que] me señalaron el lugar donde yacían aquellos tesoros. Mi resistente paciencia y mi insaciable interés por la música, hicieron lo demás ${ }^{21}$.

Así, para los años cuarenta del siglo XX ya había nociones sobre la existencia de música anterior a las guerras de independencia, que empezó a ser objeto de estudio de quienes encontraron en ella una materia prima estéticamente válida para ser historiada, pues de alguna manera los músicos, acostumbrados a anteponer el gusto y la calidad musical a otros parámetros, trabajaron el material que a su juicio era bueno, además que merecía que se conociera más sobre quién lo había compuesto. Probablemente esta actitud no fue motivada solo por el placer personal, sino que existió otro tipo de móvil, como veremos enseguida.

Con cierta frecuencia encontramos en la bibliografía cierto afán por realzar la actividad musical del momento, compararla con lo que sucedía en Europa y concluir que los países hispanoamericanos poseían también música de muy buena calidad; en esta misma línea, quienes trabajaban la música colonial intentaron igualar la práctica colonial con la música europea de la época. Autores como Juan Bautista Plaza difundieron esta idea, particularmente en su conferencia, publicada por primera vez en 1965, "La música colonial venezolana al día con la europea”, donde dice que la música colonial venezolana fue hecha por:

[...] grandes artistas que supieron aprovechar el aporte musical [...] para crear obras geniales y magníficas, siguiendo la técnica europea pero solamente en cuanto al estilo, pues la substancia musical y expresiva era distinta ${ }^{22}$.

Otro enfoque en esta misma línea es el planteado por Jesús Estrada, quien justifica su libro así:

Ha ocurrido con las vidas de los grandes compositores europeos que, después de admirar el genio realizado en sus obras, se han convertido en temas favoritos de biógrafos e historiadores. Del gusto, siempre cambiante, por tales o cuales obras ha dependido el interés por la vida de los músicos. [...] ¿Por qué esperar, pues, a la posibilidad más o menos remota de que la música de nues-

20 “[...] porque al fin y al cabo eso [la historia] contribuiría en parte a ayudarnos a averiguar de dónde somos criollos”. En Osorio, "Breves apuntamientos”, 163.

21 Sas, "La vida musical en la Catedral de Lima”, 9.

22 Juan Bautista Plaza, "La música colonial venezolana al día con la europea”, Revista Musical de Venezuela (Caracas), 6, núm. 15-17 (enero-diciembre 1985): 50. 
tros hombres, compuesta en un medio muy distinto, se haga famosa y se escuche por un amplio público antes de dar a conocer lo que hemos podido averiguar sobre sus vidas? No hay razón para la espera, y esto es lo que justifica la aparición de estas crónicas $[\ldots]^{23}$.

De esta manera la historia de la música sirvió para legitimar la práctica musical de sus países frente a la tradición europea, vista como ajena en medio del ambiente nacionalista.

\section{¿Historias de músicos o de la música?}

En 1985, Egberto Bermúdez exponía, a raíz de las historias de la música en Colombia escritas por José Ignacio Perdomo Escobar, la diferencia entre las historias de la música divorciadas de elementos sociales, económicos y políticos, y las centradas en los músicos, como fue el caso de los trabajos de Perdomo Escobar ${ }^{24}$. Ese mismo año, Juan Carlos Estenssoro entregaba su trabajo para optar al título de bachiller en Humanidades con mención en Historia, de la Universidad Católica del Perú, titulado Música y sociedad coloniales. Lima 1680-1830, el cual sería publicado cuatro años más tarde al obtener mención honorífica del Premio Robert Stevenson en Musicología e Historia de la Música Americana (OEA). Este hecho nos demuestra que la necesidad de una historia social de la música era una inquietud que pasaba por la mente de quienes -en la década de los ochenta- se relacionaban con la historiografía musical colonial. Años antes, en 1976, Robert Stevenson también tocaba el tema en un breve artículo, al decir que así como los ríos Éufrates y Tigris se unen, se deben unir también las historias de la música con las historias de los músicos, para evitar caer en errores como adjudicar obras a compositores ya fallecidos ${ }^{25}$.

Encontramos así que, durante la segunda mitad del siglo XX, la historia de la música se ha movido con tres tendencias: hacer historias sociales, hacer historia de músicos y hacer historia de la música como tal. Dentro del material que revisamos, es decir, el correspondiente a los cien años trascurridos entre 1876 y 1976, es muy incipiente la preocupación por entretejer las referencias musicales con la sociedad en que se produjeron, apareciendo esta inquietud con fuerza hasta los años ochenta. Por otra parte, la dicotomía entre los músicos y la música se vive constantemente en los autores estudiados; sin embargo, sería reduccionista clasificar la historiografía musical colonial en historias de la música e historias de músicos puesto que no son ni lo uno ni lo otro. Por lo general, todos los autores mencionan la posibilidad que tuvieron de oír la

23 Jesús Estrada, Música y músicos de la época virreinal, 2 ed. (1973; reimpresión, México: Diana, 1980): 163-164.

24 Egberto Bermúdez, “Historia de la música vs. historias de los músicos”, Revista de la Universidad Nacional (Bogotá), 1, núm. 3. (1985): 5-17.

25 Robert Stevenson, "Rumbos de la investigación sobre música colonial latinoamericana”, Revista Musical Chilena (Santiago), 134, (abril-septiembre 1976): 3-8. 
música a la que se refieren (en este punto, no se diferencian quienes tienen formación musical de quienes no la tienen). En varias ocasiones encontramos textos cuyos autores son prolíficos compositores o músicos profesionales que centran sus relatos únicamente en la vida de quienes estuvieron vinculados a la actividad musical, dejando a la música como tal relegada a someras menciones. Hay otros casos donde autores sin conocimientos musicales profundos se asesoraron de músicos activos y dejaron en sus manos la crítica musical y la trascripción y análisis de partituras; este es el caso de Eugenio Pereira Salas, quien contó con la colaboración del compositor Jorge Urrutia Blondel, y el de Gabriel Saldivar, quien fue asesorado por Elisa Osorio.

\section{¿Qué es música colonial?}

Recientemente, Bernardo Illari, en su trabajo Polychoral Culture: Catedral music in Plata (Bolivia) 1680-1730, llamó la atención sobre el uso del término colonial, al aclarar que en su caso se entenderá como música colonial toda aquella existente durante la dominación hispánica, teniendo en cuenta que actualmente este término sirve para designar también otras formas de dominación, de acuerdo con las corrientes teóricas del colonialismo ${ }^{26}$. Esta aclaración que hace Illari nos sirve para precisar el término "música colonial” pues nosotros lo usamos para calificar a toda la música que se compuso, tocó y oyó durante los tres siglos y más de dominación española que vivieron los países americanos sin hacer distinciones entre música de negros, de indígenas o de españoles y procurando contemplar a todos los estratos sociales.

En la revisión encontramos que esta noción de música colonial no es nueva sino que para autores anteriores la expresión también ha tenido el mismo valor. Esto significa que el término “colonial”, aplicado a la música, no ha buscado caracterizar particularidades estilísticas ni musicales propias sino que ha estado dado por la cronología de la historia general hispanoamericana.

Dentro de los trabajos revisados, ninguno de los autores propone con convencimiento definir un tipo de música especial ni un estilo 27 bajo el término “música colonial” sino que usan la clasificación del tiempo histórico para denominar la música del período; por lo tanto, también son frecuentes apelativos como "música de la antigüedad”, "música en tiempos de la Colonia”, "música de la época colonial”, "música virreinal” o

26 Bernardo Illari, Polychoral Culture: Catedral Music in La Plata (Bolivia), 1680-1730 (Tesis doctoral, Universidad de Chicago, 2001): 1

27 La musicología acuñó el concepto de estilo para nombrar un conjunto de características musicales que identifican a un compositor, un período, un área geográfica o una sociedad. Esta búsqueda de características musicales, que permiten hablar de cierto estilo, es una pregunta propia de la historiografía musical; por este motivo, revisamos con cuidado si en los trabajos sobre música colonial se habló de la existencia de un estilo musical propio del período histórico. Véase: Robert Pascall, “Style”, The New Grove Dictionary of Music and Musicians, ed. Stanley Sadie (Nueva York: MacMillan, 2001). Obtenido en la red mundial el 2 de febrero de 2004, 9:45 horas. http://www.grovemusic.com. 
"música durante la dominación hispánica”, usados indiscriminadamente, y se pone como fecha límite del período el año de independencia de cada país. Tal es así, que en el caso cubano, donde el período colonial español se extendió hasta finales del siglo XIX, Zoila Lapique titula su recopilación de partituras del siglo XIX como Música colonial cubana $(1979)^{28}$.

Sin embargo, si se mira la música como tal, se ve que -como dijimos páginas atrásella transitó por las colonias españolas durante los siglos XVI, XVII y parte del XVIII y mantuvo cierta homogeneidad cercana a las formas polifónicas españolas, y se diferenció de la estética italiana llegada al continente en el siglo XVIII; esta variación estuvo ligada al cambio de gobierno de los Habsburgo por el de los Borbones, pues las nuevas condiciones políticas y sociales trajeron consigo la internacionalización del gusto musical, permitiéndose la entrada a las colonias españolas de la música italiana y la ópera del siglo XVIII y XIX. Este cambio estilístico, que en algunos países se dio desde el siglo XVIII y en otros hubo que esperar hasta mediados del XIX, también coincidió grosso modo con las guerras de independencia; sin embargo, los tres siglos de contacto con el imperio español no ocasionaron la creación de un estilo musical que pueda ser llamado música colonial, ni ha habido quien lo proponga hasta el momento de esta manera.

\section{El manejo del tiempo}

Aunque las historias de la música colonial estudiadas dividen sus capítulos por lugares geográficos y otras de acuerdo con las categorías en que el autor clasificó la música, el orden interno de los capítulos y la estructura general son predominantemente cronológicos. El orden de los relatos está establecido según la aparición del fenómeno en el tiempo y, aunque varían en precisión, es visible la preocupación de todos los autores por organizar el material según ciertas fechas o hechos históricos.

En el caso de la historia de la música de José Sáenz Poggio, donde no se dan fechas exactas, el autor organiza su relato sobre lo colonial teniendo como referencia temporal el traslado de la capital de Guatemala. Tenemos también el caso del trabajo del padre Pedro Grenón Nuestra música instrumental (1929), el cual es una cronología de todas las referencias que el autor halló sobre algún aspecto de la actividad musical argentina. Como último ejemplo está la producción del estadounidense Robert Stevenson, tal vez el autor más preocupado por la cronología, pues en sus escritos demuestra una fina puntería para cazar en los archivos fechas y años, que han justificado artículos enteros, aclarando algún impase en la organización cronológica. De manera esquemática, podríamos decir que muchos de los libros y artículos de Stevenson son la organización cronológica de datos recopilados sobre algún tema musical.

28 Zoila Lapique, Música colonial cubana (La Habana: Letras Cubanas, 1979). 
Aunque la preocupación por establecer una secuencia cronológica es una constante en los trabajos de historia, sea musical, social, política o de cualquier otro tema, llama la atención cómo en la mayoría de los escritos sobre música colonial predominó el interés por las fechas sobre el análisis o comparación de los fenómenos enunciados. Sería interesante ver si la nueva producción musicológica continúa repitiendo este esquema.

Otra idea recurrente en los trabajos anteriores a los años sesenta en el manejo del tiempo es la constante búsqueda de los orígenes, bien sea con fines nacionalistas o por el interés que este asunto produjo en su momento. Esta búsqueda se puede ver en el manejo del tema indígena desde el cual los autores esperan poder explicar el trascurso posterior, es decir, buscando los orígenes allí para poder aclarar el resto de la historia, con la idea de que la música evoluciona desde lo primitivo hacia algo superior: lo actual. Desde luego, el interés por los orígenes muestra una clara influencia de la historiografía positivista en estos trabajos.

\section{Biografías}

La presencia de la biografía ha sido una constante en la historiografía sobre la música del período colonial, unas veces apologética y otras veces minuciosa, en datos como en fechas y lugares. Un gran número de artículos publicados en revistas especializadas y posteriores a los años sesenta insisten en precisar o desmentir este tipo de información. El interés biográfico también estuvo patrocinado por la inclusión en algunas enciclopedias de música de entradas para compositores hispanoamericanos ${ }^{29}$; esto ocasionó que los editores encargaran a los especialistas artículos sobre algunos músicos, y así se dio un empuje significativo al género biográfico. Entre estos diccionarios cabe destacar la reciente publicación en diez tomos del Diccionario de la música española e hispanoamericana (1999), dirigida y coordinada por Emilio Casares Rodicio, catedrático de musicología de la Universidad Complutense de Madrid.

De esta manera, se ha privilegiado el estudio de compositores y no el de músicos, con el ingrediente adicional de que a aquellos se les ha atribuido la responsabilidad de la calidad musical de su momento y, por lo tanto, la historia evolucionista de la música los ha convertido en eslabones del progreso de su región. En la calidad de la obra del compositor recae la valoración de una buena o mala época, lo cual no sucede con los intérpretes, en quienes no se ha centrado la atención. Este énfasis puesto en el compositor nos recuerda la visión romántica de la genialidad y nos hace considerar que este tipo de culto ha seguido vigente en el siglo XX. En este punto, la preocupación de la historia de la música por las grandes figuras se asemeja al interés de la historiografía positivista por los grandes héroes.

29 New Catholic Encyclopedia (1961), The New Grove Dictionary of Music and Musicians (2001). 
Uno de los compositores más trabajados ha sido el italiano Doménico Zipoli, quien desde 1941 llamó la atención de Lauro Ayestarán ${ }^{30}$ y desde entonces ha merecido varios trabajos históricos y discográficos, por la calidad de su composición ${ }^{31}$. De igual manera, se ha puesto empeño en conocer las vidas de otros compositores como Esteban Salas, quien trabajó en Santiago de Cuba; José Cascante, en Nueva Granada; Tomás de Torrejón y Velasco, Juan de Araujo, Roque Ceruti, Antonio Durán de la Mota, en el virreinato del Perú, y Juan Gutiérrez de Padilla, Manuel de Sumaya y Hernando Franco, en la Nueva España, entre otros.

Otra manera de constatar que la musicología ha hecho biografía de compositores es en la trascripción y grabación de sus obras. En México se inició en 1952 la colección Tesoro de la música polifónica en México, cuando Jesús Bay y Gay transcribió el "Códice del Convento del Carmen” que incluía composiciones de varios músicos coloniales. Posteriormente, la colección publicó su segundo tomo, en 1981, con 13 obras de la Colección J. Sánchez Garza, y actualmente va en el tomo número 10, habiendo trascrito obras de Gaspar Fernández y Manuel de Sumaya, entre otros. Al respecto, decía Bal y Gay:

Los trabajos realizados hasta ahora con vista a perfilar la historia de la música mexicana se limitan casi exclusivamente a la investigación biográfica. Sin pretender negar la importancia de tales trabajos, indiscutiblemente necesarios, consideramos no menos necesario y urgente el conocimiento de la música misma, tal y como se practicó en su tiempo ${ }^{32}$.

¿Pero, con qué criterio se ha escogido trabajar estos compositores? Aunque es difícil responder a esta pregunta, al leer los trabajos escritos se pensaría que su escogencia nace de la calidad de la obra y de la importancia que ella tiene para la música actual; otras veces se puede concluir que se le dio importancia al compositor, pese a que la calidad musical no fue considerada alta, y no por haber nacido en una país hispanoamericano y representar lo que en ese momento la escuela de composición local alcanzara. Por otra parte, es muy posible que estos nombres de compositores conocidos hoy en día estén relacionados más con la documentación disponible que con otros motivos.

Las biografías anteriores a la llegada de la musicología por lo general realzan aspectos de la vida del compositor, tanto profesionales como personales. Para autores como

30 Ayestarán, Doménico Zipoli. El gran compositor.

31 Entre los trabajos recientes sobre este compositor se puede mencionar el CD: Domenico Zipoli, Martín Schmid et compositeurs indegènes anonymes. San Ignacio L'opera perdu des missions jésuites de l'Amazonie, dir. Gabriel Garrido (France: K617; Festival d'Ambronay avec le concourts du conseil general de l’Ain, 1996), y el Premio de Musicología Casa de las Américas en su IX versión, otorgado al trabajo de Bernardo Illari “Zipoli: para una genealogía de la música clásica latinoamericana”.

32 Jesús Bal y Gay, Tesoro de la música polifónica en México. El códice del Convento del Carmen (México: Instituto Nacional de Bellas Artes, 1952): ix. 
Juan Bautista Plaza el carácter generalmente bondadoso y muy cercano al modelo cristiano de santidad eran características de los grandes maestros, mientras que para las biografías hechas con los parámetros de la musicología estas características perdieron casi total relevancia y fueron remplazadas por mayor información sobre la formación musical, los maestros y discípulos, para poder hallar así conexiones que ayudaron a entender el estilo de cada compositor.

\section{Temas y enfoques}

Hemos visto que a lo largo del tiempo los temas tratados al hablar de música colonial son constantes y el mayor o menor énfasis puesto por cada autor está vinculado con las diferentes tendencias intelectuales o con el grado de generosidad de las fuentes que hayan manejado. Todos los trabajos consultados tocan temas como la música indígena, la música y las fiestas de los esclavos, e ineludiblemente resaltan la actividad musical de las catedrales, haciendo referencia a los maestros de capilla, músicos y repertorio; se ocupan también de la música en las misiones o de la labor evangelizadora de la iglesia, de los instrumentos musicales usados tanto en la iglesia como fuera de ella y de la música profana, llamada actualmente doméstica.

\section{Música de los indígenas}

Comúnmente, dentro de las historias de la música, antecede al capítulo sobre el período colonial un aparte titulado "música indígena". Autores de finales del siglo XIX e inicios del XX, como el venezolano Ramón de la Plaza, solían hablar en este primer apartado sobre la música prehispánica -obedeciendo al orden cronológico-, y después, en el capítulo siguiente, volvían a hacer referencia al elemento indígena, generalmente relacionado con la labor en las misiones.

En la mayoría de los casos las menciones de la música de los indígenas tienden a poner en el mismo plano temporal las deducciones que gracias a la arqueología los autores pudieron hacer en relación con lo prehispánico, las descripciones de cronistas sobre la presencia indígena en algún aspecto de la actividad musical colonial y las observaciones etnográficas que sus contemporáneos o ellos mismos hicieron en comunidades indígenas vivas. Este es el único momento en que los relatos sobre música colonial rompen el orden cronológico.

Sin embargo, consideramos que esta característica no es causada por un descuido de los autores o por un mal ordenamiento del texto final, sino porque existió la idea común de que el mundo indígena era inmutable y no cambiaba en el tiempo, y se llegó a considerar que no hubo variaciones desde las prácticas musicales prehispánicas hasta las actuales. Esta idea de la inmutabilidad del mundo indígena está relacionada con el auge que tuvieron los estudios de folclore en los años cuarenta. Para el folclore las tradiciones orales son estáticas y se trasmiten de generación en generación de mane- 
ra natural, sin que el paso del tiempo las afecte, $\mathrm{y}$, por lo tanto, la labor de los folcloristas debía ser estancar el “dañoso” proceso de cambio en el que se veían involucradas las tradiciones al ser tocadas por la modernidad ${ }^{33}$. No en vano, durante las décadas del cuarenta y cincuenta se abrieron en varios países hispanoamericanos institutos dedicados a esta labor, como por ejemplo el Instituto de Investigaciones del Folklore Musical de Chile, fundado en 1944, donde trabajó Eugenio Pereira Salas -autor de Los orígenes del arte musical en Chile (1941)-; la Sección de Folklore y Artes Populares en Perú, en 1945; la Sección de Investigaciones Musicales, sub-sección de Investigaciones Folklóricas de México, en 1946, a cargo de Vicente T. Mendoza, quien es reconocido por sus trabajos sobre el corrido mexicano; el Instituto de Folklore de Venezuela, en 1947, dirigido por Luis Felipe Ramón y Rivera -alumno de Carlos Vega-; el Departamento de Folklore del Ministerio de Educación de Bolivia, en 1954; el Centro de Estudios Folklóricos y Musicales de la Universidad Nacional de Colombia, en 1959, y el Instituto Ecuatoriano de Folklore, en $1961^{34}$.

Cuando empezaron a publicarse los trabajos centrados en el período colonial, el problema de la confusión entre lo prehispánico, lo colonial y el presente desapareció, pero no por causa de un debilitamiento de la postura inicial sino porque sus autores no volvieron a tratar el tema indígena sino solo a partir de la llegada de los españoles. Para investigadores como Samuel Claro, Jesús Estrada y Pablo Hernández Balaguer la figura del indio fue importante en la medida en que participó en este período, no antes ni después, es decir solo en el papel que desempeñó durante la dominación hispánica.

Robert Stevenson, que trabajó con detenimiento la historia musical colonial de México y de Perú, dos de los países con mayor población indígena viva, prefirió dedicar un par de capítulos a describir lo que pudo ser su música antes de la Colonia, usando instrumentos musicales de museos arqueológicos y los testimonios dados por los cronistas. Esta organización del relato en sus trabajos tempranos no parece ser una reacción explícita contra la confusión entre el tiempo prehispánico y el colonial indígenas, sino que es una organización estrictamente cronológica del material que el autor tuvo a mano. Este material fue tan abundante que permitió la escritura de capítulos referidos solo a este tema y, posteriormente, del libro Music in Aztec \& Inca Territory (1968), en el cual hace un recuento del elemento indígena en sus fases prehispánicas y coloniales musicales bien diferenciadas ${ }^{35}$; no obstante, se puede observar en escritos pos-

33 Sobre el desarrollo del folclore y la etnomusicología en Colombia, véase: Carlos Miñana Blasco, "Entre el folklore y la etnomusicología. 60 años de estudios sobre la música popular tradicional en Colombia” A contratiempo. Revista de Música en la Cultura (Bogotá), 11 (2000): 36-49.

34 Isabel Aretz, Historia de la etnomusicología en América Latina. Desde la época precolombina hasta nuestros días (Caracas: Fundec; Conac; OEA, 1991).

35 El libro Music in Azteca and Inca Territory (1968) se compone en su gran mayoría de los textos sobre música indígena publicados en sus libros anteriores Music in México. A Historical Survey (1952) y The music of Peru. Aboriginal and Viceroyal Epoch (Washington: Pan American Union, 1960). 
teriores que el autor siguió trabajando al indígena y lo relacionado con él, solo en el marco del período colonial, sin incluir datos etnológicos ni arqueológicos.

Por otra parte, si relacionamos la presencia del tema indígena con la densidad que tiene este grupo de población en el territorio estudiado por los autores, no es de extrañar que los trabajos de Gabriel Saldivar, en México, los trabajos sobre Perú y Bolivia de diferentes autores o, actualmente, los de Dieter Lehnhoff en Guatemala posean un marcado interés por este tema; o que exista el caso contrario en países como Uruguay, donde Lauro Ayestarán lamentó la inexistencia de comunidades indígenas vivas que permitieran profundizar en el estudio de su música ${ }^{36}$. Creemos que esta circunstancia no solo hace que los autores se pregunten por el tema, puesto que son inquietudes que surgen de su entorno cotidiano, sino que ayuda a que las fuentes documentales sean más ricas que en otros países, como por ejemplo en Colombia, donde hasta el presente no tenemos noticias de la existencia de partituras con textos en lenguas indígenas, lo cual es común en México.

Actualmente, tras la llegada de la etnomusicología y con los avances de la antropología, los estudios sobre música colonial han hecho relecturas del tema indígena concibiendo al indígena como un individuo activo dentro del sistema colonial que merece un tratamiento mucho más cuidadoso que el dado desde las posturas anteriores. El actual auge que tiene la música indígena colonial como tema de estudio está también ligado al interés que hoy despiertan las minorías éticas -no solo la indígena- como una reacción ante el tema de la globalización.

Otro aspecto interesante de tratar es el relacionado con la valoración subjetiva y muchas veces sustentada en términos raciales que en algunas oportunidades dejaron salir a la superficie los autores cuando tocaron el tema de lo indígena y de lo negro. Veamos: en la documentación colonial del continente hispanoamericano, son repetitivas las referencias que algunos observadores hicieron de la capacidad musical que tenían los indígenas, la facilidad con que aprendían la teoría musical y la maestría con que tocaban los instrumentos que sus maestros europeos les enseñaban. Es posible que el ensalzamiento de esta capacidad musical se deba en gran medida a la sorpresa que causaba entre los españoles el hecho de que estos indios, a quienes consideraban inferiores en lengua, religión, cultura e inteligencia, pudieran interpretar piezas del repertorio occidental con la misma calidad que se daba en España; desde luego, este planteamiento se puede matizar con elementos de orden económico y político que no trataremos aquí. Sírvanos este ejemplo para asemejar la actitud de los cronistas a la de los investigadores que trabajaron la música colonial en la primera mitad del siglo $\mathrm{XX}$, pues consideramos que estas narraciones - muchas veces citadas- atrajeron a

36 Ayestarán, La música en el Uruguay, 15. 
los autores porque rompían la idea de lo primitivo y no evolucionado que permanecía en el inconsciente intelectual de la época ${ }^{37}$.

\section{Música de los esclavos africanos}

Otro de los temas constantes en los trabajos sobre música colonial son las referencias a la actividad musical de la población negra. Al igual que el tema indígena, la mayor o menor importancia que dieron los autores a la materia está mediada por la fuerza y cantidad de población de origen africano o con rasgos raciales que así los acrediten en cada país ${ }^{38}$.

Dentro de los trabajos que revisamos, la mayoría de los autores coincide en afirmar que el elemento africano es fundamental para la historia de la música hispanoamericana y recurren a documentación donde las autoridades coloniales describen los bailes que los esclavos realizaban y la música con que se acompañaban, para luego juzgar si se hizo bien en prohibirlos o no, y concluir que, pese a los esfuerzos por castigar y corregir, la música de los esclavos sobrevivió y hoy es un elemento importante de nuestra identidad criolla, mezcla de tres razas: blanca, negra e indígena. Este es el discurso típico en el que se enmarcó la cuestión de la música de los negros del período colonial, en la primera mitad del siglo $\mathrm{XX}^{39}$.

En trabajos posteriores producidos por la musicología no hemos encontrado una postura que reevalúe el papel que le adjudicó la historiografía anterior a la música que pudieron tocar o componer los esclavos llegados a América, y que -en nuestra opinión- no se ha podido sustentar claramente. En 2002, en el marco del IV Festival Internacional de Música Renacentista y Barroca Americana, se dieron a conocer trabajos sobre este tema en el simposio titulado "Mujeres, negros y niños en la música y sociedad colonial iberoamericana" ${ }^{40}$, en el que se presentaron ponencias que, ha-

37 El término "inconsciente intelectual” fue enunciado inicialmente por Jean Piaget en el marco de la psicología genética y ha sido luego articulado al cuerpo teórico de la historia de las ciencias por Emilio Quevedo en su investigación sobre la construcción del concepto de fiebre amarilla selvática en Colombia. Bajo esta categoría se entienden todos aquellos conceptos que habitan en la mente de los científicos e investigadores y de cuya existencia y uso ellos no son conscientes y que son visibles en la configuración de sus productos intelectuales. Emilio Quevedo y otros, "La construcción del concepto de fiebre amarilla selvática en Colombia 1906-1948” (proyecto de investigación, Universidad Nacional de Colombia; Banco de la República; Colciencias, Bogotá, 2003).

38 Por no contar para este balance con toda la bibliografía sobre Centroamérica ni haber incluido a Brasil, donde precisamente se encuentran las mayores concentraciones de afro-descendientes, no podremos documentar esta suposición, pues solo tenemos para el caso cubano el trabajo de Alejo Carpentier, al que ya nos referimos.

39 Véanse como ejemplos: Moreno, "La música en el Ecuador”; Saldivar, Historia de la música en México; Pereira, Los orígenes del arte musical en Chile; Jacob M. Coopersmith, Music and Musicians of Dominican Republic (Washington: PAU, 1949), entre otros.

40 Víctor Rondón ed., Mujeres, negros y niños en la música y sociedad colonial iberoamericana. IV Festival Internacional de Música Renacentista y Barroca Americana "Misiones de Chiquitos" (Santa Cruz de la Sierra: Asociación ProArte y Cultura APAC, 2002). 
ciendo uso del método comparativo entre tradiciones vivas y documentos de archivo, comparando fenómenos similares en diferentes lugares de Latinoamérica y recurriendo al trabajo biográfico, buscaron profundizar en las dinámicas que giraron en torno al papel de los esclavos en la actividad musical colonial; gracias a sus aportes, el estudio de este tema se vio enriquecido por nuevas preguntas y herramientas conceptuales.

Por último, este es un tema que, para el período colonial, no ha convocado a muchos musicólogos ni etnomusicólogos -y mucho menos a historiadores o antropólogos-, pese a la gran producción que la historiografía colonial ha generado respecto a otros aspectos del papel de los esclavos en el medio colonial, y que muy seguramente pueden dar herramientas para entender de otra forma su actividad musical. Hechos como este ponen de manifiesto la brecha que existe entre las disciplinas de la historia y la musicología, en este campo.

\section{Música en la catedral}

Este es el aspecto más trabajado de la actividad musical colonial, pues desde 1876, cuando Guerrero Toro publicó su historia de la música ecuatoriana, hasta la tesis doctoral de Bernardo Illari presentada en 2001, se ha retomado muchas veces la música catedralicia para conocer en qué consistió la actividad musical colonial.

Tal vez por el desdeño con que la inicial historiografía trató al período colonial, el programa catedralicio llamó la atención de quienes se interesaron en la materia, ya que sus archivos permitieron desmentir la idea sobre la pobreza musical anterior al siglo XIX. Al abrirse estos fondos documentales, los investigadores pudieron ver que la Iglesia tuvo políticas certeras para mantener una actividad musical de buena calidad en las capitales de los virreinatos, como mínimo, y que después de las guerras de independencia estos lugares no volvieron a tener la riqueza musical que reunieron en el tiempo colonial, lo cual era una diferencia notable con el presente y una justificación válida para que los autores dedicaran al tema muchas páginas.

Una característica notoria en la historiografía sobre la música en las catedrales es la fuerte influencia de los principios positivistas que permearon a la historia de las primeras décadas del siglo XX. Este influjo lo identificamos en la búsqueda y anotación detallada de todos los datos encontrados. Por lo general, se hicieron listados de los sucesivos maestros de capilla ${ }^{41}$ que ocuparon el cargo y, en la medida en que la documentación lo permitió, estas listas se elaboraron en forma pormenorizada con datos como fechas de nacimiento o muerte, lugar de origen, composiciones y habilidad en materia musical. Este último aspecto algunos autores lo retomaron de los contemporáneos del compositor y otros lo propusieron después de analizar sus partituras.

41 Músico encargado de la dirección musical de la catedral, lo cual incluía componer, enseñar y organizar los ensayos y conciertos. 
En los años sesenta, la musicología hizo una innovación a los datos recopilados para completar estas listas e introdujo las referencias necesarias que permitieran hacer genealogías de la formación musical de los compositores con el fin de identificar estilos o vínculos con otros compositores europeos y americanos. Estos nuevos datos obligaron a los investigadores a romper las fronteras nacionales y a pensar en la unidad del imperio español, pues fue frecuente que los compositores se movilizaran entre las capitales y ciudades de los virreinatos y fueran dejando partituras y alumnos a su paso, los cuales fueron muy buscados por los investigadores.

Para quienes estudiaron este tema, otro aspecto importante fue la vida de los músicos y cantantes que trabajaron en la catedral, sus salarios y cualquier dato que ayudara a conocer algo más de sus vidas: matrimonios, hijos, viajes, etc. ${ }^{42}$ También la compra de instrumentos y las veces que se reparó el órgano, uno de los principales instrumentos de la música religiosa. Para ampliar la visión de la música eclesiástica -como se suele llamar- se echó mano de notas sobre conventos y fiestas públicas, como el Corpus Christi, donde generalmente trabajaron los músicos empleados en la catedral. Y así fueron incluidos otros escenarios donde la música ocupó algún espacio.

Al hablar de música catedralicia es interesante resaltar las investigaciones del mexicano Jesús Estrada y del venezolano Juan Bautista Plaza, músicos organistas formados en la Pontificia Escuela Superior de Música Sacra en Roma antes del Concilio Vaticano II, que, por lo tanto, debieron aprender y adoptar toda la tradición litúrgica y musical manejada por la Iglesia católica desde el siglo XV propuesta por la Contrarreforma, la cual -como sabemos- fue aplicada con rigurosidad en las colonias americanas. La formación de este par de autores hace que sus trabajos sean notorios por presentar elementos que relacionan muy bien la música eclesiástica con el culto católico. De esta misma forma también son atrayentes los textos de Robert Stevenson, quien estudió teología después de ser músico y además hizo trabajos sobre la música española de los siglos XVI, XVII y XVIII, de la cual -como él ha demostrado- se desprende gran parte de nuestra música colonial.

42 Entre los muchos trabajos que ejemplifican esta tendencia podemos citar: Robert Stevenson, "Mexico City Cathedral Music 1600-1675”, Inter-American Music Review (Los Angeles), 9, núm. 1 (otoñoinvierno 1987): 75-113; Cathedral Music in Colonial Peru (Lima: Pacific Press, 1959); "El archivo musical de Bogotá”, trad. Andrés Pardo Tovar, en La música colonial en Colombia (Cali: Instituto Popular de Cultura de Cali, 1964); "La música colonial en Colombia”; José Ignacio Perdomo Escobar, El archivo musical de la catedral de Bogotá (Bogotá: Instituto Caro y Cuervo, 1976); Samuel Claro, Catálogo del Archivo Musical de la Catedral de Santiago de Chile (Santiago: Instituto de Extensión Musical; Universidad de Chile, 1974); Estrada, Música y músicos; Carmen García Muñoz y Waldemar Axel Roldán. Un archivo musical americano (Buenos Aires: Eudeba, 1972); Andrés Sas, La música en la Catedral de Lima durante el Virreinato, 2 vols. (Lima: Universidad Nacional Mayor de San Marcos; Instituto Nacional de Cultura, 1972); “La vida musical en la Catedral”; Pablo Hernández Balaguer, "La capilla de música en la catedral de Santiago de Cuba”, Revista Musical Chilena (Santiago), 18, núm. 19 (octubre-diciembre 1964): 14-61; Catálogo de música de los archivos de la Catedral de Santiago de Cuba y del Museo Bacardí, 2 ed. (Santiago de Cuba: Editorial Oriente, 1979); Calcaño, “Música colonial venezolana”; Francisco Curt Lange, La música eclesiástica en Córdoba durante la dominación hispánica (Córdoba: Universidad Córdoba, 1956); y Spell, "Music in the Cathedral”. 


\section{Música en las misiones}

Ya desde los inicios de la historiografía musical los autores hablaban del empeño que tuvieron los misioneros en la enseñanza musical a los indígenas, y autores como Guillermo Furlong y Gabriel Saldivar identifican este esfuerzo como un medio para lograr atraer a los indígenas al culto católico. A través del tiempo, esta hipótesis se ha visto sustentada por nueva documentación, y aún hoy no ha sido revaluada sino que continua siendo un supuesto de las investigaciones.

Actualmente, este es el tema que mayor bibliografía está produciendo respecto a la música colonial, y creemos que se encuentra motivado por los ricos archivos existentes en la región de las misiones de Moxos, Chiquitos y Guaraníes en los actuales territorios de Bolivia, Paraguay y norte de Argentina. Estos archivos son ricos en partituras y documentación que permite contextualizar las prácticas musicales, por lo cual han atraído a un grupo grande de musicólogos que los han trabajado y están buscado conocer si existe en otros lugares más documentación de este tipo, para poder entender mejor la manera como funcionó el contacto entre misioneros e indígenas en un contexto de dominación y supervivencia. Como mencionábamos al inicio del artículo, este es un tema que ha motivado en los últimos veinte años estudios interdisciplinarios entre la historia, la etnomusicología y la musicología ${ }^{43}$.

\section{Instrumentos musicales}

La relativa facilidad con que se encuentran referencias a instrumentos musicales en documentos de los archivos históricos hispanoamericanos ha generado que este sea otro de los temas mencionados comúnmente. Y hablamos de "relativa facilidad" por la diferencia en el acceso que ha habido entre los archivos eclesiásticos y los archivos históricos, pues la entrada a los archivos catedralicios, que están por lo general guardados y custodiados para que no se sepa de su existencia, se debe a factores más circunstanciales que intelectuales; en cambio, documentación colonial como testamentos, libros de aduana, inventarios y otros fondos que reposan en los archivos históricos se pueden consultar tras una mezcla de curiosidad, paciencia y suerte por parte del investigador.

Durante la primera mitad del XX los investigadores usaron las referencias a venta o compra de cuerdas de guitarra, las herencias dejadas de vihuelas o clavicordios, los contratos por reparación de arpas y órganos, ventas de violines y laúdes o los juicios por deudas y demás circunstancias gracias a las cuales la presencia de instrumentos

43 Por ejemplo, Irma Ruiz y Gerardo Huseby, "Pervivencia del rabel europeo entre los Mbïa de Misiones (Argentina)” Temas de Etnomusicología (Buenos Aires), 2 (1986): 67-97; Ruiz, "Herederos de la colonización jesuítica”; "Dos respuestas al proyecto jesuítico: música y rituales de los chiquitano de Bolivia y de los mbyá de la Argentina” Música e Investigación (Buenos Aires), 1, núm. 2 (1998): 79-97. 
musicales quedó consignada en el papel, para sustentar una prolífica actividad musical profana en la Colonia.

Con la llegada de la musicología apareció también la especialización en organología, es decir, en el estudio de los instrumentos musicales a través de su historia y de su función social ${ }^{44}$. Esta propuesta de estudio, sumada al deseo por poner a sonar las partituras encontradas y la entrada en escena de los músicos profesionales, interesados en tocar el repertorio colonial, ocasionó que el estudio de los instrumentos musicales coloniales se convirtiera en un campo de trabajo especializado cuyo fruto produjo no solo artículos y textos sino la elaboración de réplicas de instrumentos antiguos que reproducen lo más de cerca posible las sonoridades que los materiales y técnicas de construcción pudieron crear en su momento.

\section{Música doméstica}

Como dijimos anteriormente, las referencias a instrumentos musicales diferentes a los usados en las iglesias y catedrales permitió a los autores hacer alusión a otra esfera de la actividad musical: la no eclesiástica.

Al principio, usando un poco de imaginación, los autores decimonónicos describieron la apacible vida de la colonia acompañada por las melodías que al atardecer se oían salir de las guitarras y vihuelas. Desde luego esta imagen romántica no estaba tomada de ningún documento sino de la unión en sus mentes de las referencias a instrumentos musicales -ya mencionadas- y la nostalgia por los viejos tiempos, despertada por el proceso de urbanización que vivía Hispanoamérica a finales del XIX.

Más adelante, en las primeras décadas del siglo XX, los trabajos de corte positivista omitieron este tipo de comentarios y se restringieron a valerse de las referencias documentales a instrumentos musicales como indicios de una práctica secular o profana.

Después de trascribir las partituras de los archivos eclesiásticos y preocuparse por estudiar el material musical en relación con su contexto, se postuló al villancico como un género usado en la iglesia pero construido con elementos provenien-

44 Entre otros trabajos, podemos mencionar a Bermúdez, "Instrumentos musicales latinoamericanos”; La música en el arte colonial; Alejandro Godoy, "Breve semblanza del órgano barroco andino” Data. Revista del Instituto de Estudios Andinos y Amazónicos (La Paz), 7 (1997): 197-217; Gonzalo Camacho, "El arpa en México colonial. Entre lo sacro y lo secular, la transculturación y la mixtura musical”, XXI International Congress. Latin American Studies Association (Chicago, septiembre 2426 1998). Obtenido en la red mundial el 20 de abril de 2004, 09:15 horas. http://168.92.200.17/gr/ libros/lasa98/CamachoDiaz.pdf; Bernardo Ilarri, “De los órganos misionales de Chiquitos y su relevancia para la práctica musical”, Resonancias (Santiago), 4 (mayo 1999): 68-81. 
tes de tradiciones populares ${ }^{65}$. Al respecto, también se ha identificado la inclusión de ingredientes en otro tipo de piezas que hablan de la música profana, popular o doméstica a través de los textos alusivos a la vida cotidiana.

Aunque este es un tema difícil de desarrollar por la escasa documentación con que se puede sustentar, la pregunta sobre la música no eclesiástica empezó a tomar importancia cuando los estudios sobre folclore miraron el pasado colonial en busca de reivindicar las tradiciones campesinas como ancestrales; este tipo de trabajos se interesaron por la música que se tocaba fuera de las iglesias, de tradición oral y propia de la gente del común, como la llamaban. Creemos que actualmente la búsqueda de la música no eclesiástica sigue vigente porque está guiada por la separación insalvable que nuestro siglo XX ha creado entre una música culta y una música popular. Sobre este tema volveremos cuando hablemos de la clasificación que han hecho de la música colonial los autores.

\section{Clasificación de la música del período colonial}

La historia de la música no ha sido inmune al hábito de ordenar y clasificar lo que se estudia. En 1976, María Ester Grebe propuso una clasificación de la música en docta, popular y tradicional, de acuerdo con si era de trasmisión oral o escrita, con el grado de difusión que tuviera, su duración en la memoria de la gente, etc. ${ }^{46}$, y aunque esta clasificación es contradictoria y no sirve para ordenar toda la música que circula en nuestro medio, su escrito nos permite ejemplificar la tendencia a nombrar y agrupar la música por características que no son musicales sino que obedecen a su contexto y enredarse en las implicaciones que esto tiene.

Al igual que Grebe, los investigadores de la música colonial también clasificaron y dividieron la música del período muchas veces usando categorías manejadas en el presente y trasponiéndolas a una sociedad donde probablemente no existieron. Todos los trabajos sobre música colonial diferencian tipos de música y usan varios adjetivos para referirse a ellos, como por ejemplo las palabras profana, secular, popular, doméstica, indígena, aborigen, religiosa, eclesiástica, catedralicia, culta o clásica. Aunque el problema de la terminología no es tratado explícitamente por ellos, es un reflejo de los parámetros que usaron para estudiar la música colonial.

45 Dieter Lehnhoff, "Elementos indígenas y africanos en el villancico guatemalteco del siglo XVI", Revista Musical de Venezuela (Caracas), 12, núm. 30-31 (enero-diciembre 1992): 203-209; Egberto Bermúdez, "El villancico de navidad: variantes coloniales de una tradición profana y religiosa española”, Revista Credencial Historia (Bogotá), 72 (diciembre 1995): 4-9; Leonardo Waisman, “Transformaciones y resemantización de la música europea en América: dos ejemplos”, Data. Revista del Instituto de Estudios Andinos y Amazónicos (La Paz), 7 (1997): 197-217.

46 María Ester Grebe, “Objeto, método y técnica de investigación en etnomusicología: algunos problemas básicos”, Revista Musical Chilena (Santiago), 133 (1976): 10. 
La mayoría de los textos no son minuciosos en la catalogación; en términos generales, enuncian una clasificación étnica diferenciando entre la música aborigen o indígena de la española y, algunas veces, de la música de los esclavos; sin embargo, esta clasificación, más que diferenciar tipos de música, se usó para dividir la actividad musical de los indígenas, negros y españoles, y no a la música misma.

Llama la atención que en los primeros trabajos, es decir, los del siglo XIX, se diferenciaban solo dos tipos de música para el período colonial: la música profana y la música eclesiástica. Pero, años después, cuando llegó el siglo XX y la práctica musical de las primeras décadas se vio dividida en dos bandos, la clasificación de la música colonial también cambió. En los años veinte y treinta del siglo XX se diferenciaron dos grupos: uno era el de los músicos salidos de los conservatorios, con formación académica, y otro el de los músicos que permanecieron en la tradición popular. Lo más notorio de este cambio fue que la diferencia no solo estaba en el tipo de educación adquirida, sino en la música misma que interpretaban, en el valor social que a cada una se le adjudicó y en el grado de acceso que tenían a los medios masivos de difusión, como la radio y la naciente industria discográfica; estas diferencias crearon una división irreconciliable entre la práctica musical académica y la práctica musical popular, surgiendo las categorías de música académica y música popular.

Por este motivo los autores que vivieron la polémica construida entre lo académico y lo popular aplicaron esta misma división a la época colonial e identificaron por lo general la primera con la música eclesiástica o religiosa y la segunda con la música indígena o profana. Precisamente, el único trabajo que dedica unas palabras a hacer explicita la clasificación es de esta época, pues Gabriel Saldivar la divide en tres ramas: la música indígena, la música de los españoles y la música popular. A su vez, a cada una de estas tres divisiones les adjudicó otras: la música indígena -según lee en los cronistas- se divide en música melancólica y música alegre; la música de los españoles se divide en música religiosa y profana, y la música popular en religiosa, semireligiosa y profana ${ }^{47}$. En nuestra opinión, Saldivar recogió la visión de sus contemporáneos sobre la división de la música entre académica y popular, y la sumó a la clasificación anterior.

Años después, cuando en la musicología tomaron fuerza los estudios sobre música popular, entendida como "mediatizada, masiva y modernizante" ${ }^{\text {", }}$ los trabajos sobre música colonial empezaron a cuidarse de no caer en el anacronismo de aplicar el término popular al tiempo colonial y optaron por regresar a la diferenciación entre música eclesiástica y música profana, matizando cada uno de estos grupos con ejemplos concretos, como el caso del villancico, al que ya nos referimos.

47 Saldivar, Historia de la música en México, 201.

48 Juan Pablo González, “Musicología popular en América Latina: síntesis de sus logros, problemas y desafíos”, Revista Musical Chilena (Santiago), 55, núm. 195 (2001): 38. 


\section{Fuentes}

En el manejo de las fuentes, la historiografía sobre música colonial estuvo muy cercana a los principios positivistas que ensalzan al documento escrito como fuente primaria principal y casi única. En la historia de la música colonial predominó el uso de dos tipos de fuentes: los documentos escritos y las partituras. No obstante, como mencionábamos al inicio del artículo, trabajos recientes han complementado la información con otro tipo de fuentes como la iconografía y la tradición oral, resaltando permanencias en las tradiciones campesinas actuales.

\section{Documentos}

Como quedó dicho, diferentes desarrollos del estudio de la música del período colonial han estado fuertemente condicionados por los hallazgos documentales más que por nuevas lecturas. De hecho, al sobreponer el mapa de los lugares donde existen archivos coloniales musicales al mapa de los lugares con más bibliografía, se halla una relación directa.

Las fuentes que los historiadores han privilegiado son los cronistas y las descripciones de la vida colonial hechas por ellos, donde hay esporádicas menciones al ambiente musical que sus autores dicen haber observado ${ }^{49}$. A causa del espacio que separa a la musicología de la historia general, la crítica documental no es común, y mucho más extraño es el ejercicio de contextualizar las crónicas que se citan. No se hacen preguntas por si realmente el cronista trabajado presenció lo que narra o si lo copió de algún manuscrito anterior, pudiendo tener implicaciones en la exactitud de las descripciones y en la permanencia en el tiempo de cierta práctica musical; tampoco se piensa en las causas que llevaron al cronista a escribir su texto y, por lo tanto, no se hace alusión a los móviles que pudieron estar detrás de -por ejemplo- una exageración sobre los "perniciosos" bailes y fiestas de los esclavos, tal vez relacionada con una crítica al pobre control ejercido por la Iglesia en el lugar, más que con la música. Por lo general, tanto los trabajos de la primera mitad del siglo XX como los que son fruto de la musicología hasta la década del setenta, no hacen este tipo de preguntas sino que confían en la información que se lee en letra imprenta como si fuera un tipo de “cámara oculta” en el pasado.

En los textos analizados es más frecuente el uso de fuentes impresas que de documentos manuscritos pertenecientes a archivos diferentes a los catedralicios. Esta tendencia la entendemos como una evidencia de la poca formación de esos autores

49 Entre otros: Osorio, “Breves apuntamientos”, 162-166; Moreno, “La música en el Ecuador”; Saldivar, Historia de la música en México; Pereira, Los orígenes del arte; Furlong, Músicos argentinos; José Ignacio Perdomo Escobar, Historia de la música en Colombia (Bogotá: Biblioteca Popular de Cultura Colombiana, 1945); "Esbozo histórico”; Gesualdo, Historia de la música; Pardo, La cultura musical. 
en la investigación histórica, pues, de nuevo, la gran mayoría proviene de la música y no de las ciencias sociales; sin embargo, existe un pequeño porcentaje con formación en la disciplina histórica, a quienes nos referiremos ahora teniendo en cuenta su manejo documental.

Un buen ejemplo de rigurosidad y experiencia en los archivos históricos es el chileno Eugenio Pereira Salas, que en 1941 publicó Los orígenes del arte musical en Chile, uno de los más completos escritos sobre el tema colonial gracias al cúmulo de documentación revisada sobre Chile y otros sitios de influencia cultural, como fueron Córdoba y Lima. Pereira Salas (1904-1979) junto con el peruano Juan Carlos Estensoro (1964-) son los dos únicos historiadores de formación que han trabajado la música colonial; sin embargo, los años que los separan se reflejan en la distancia entre sus enfoques. Aquel hizo estudios de Historia, en la Sorbona, París, con Charles Seignobos, y su historiografía se caracteriza por ser de corte enteramente positivista ${ }^{50}$, lo cual explica el cuidadoso manejo documental de sus textos; además fue miembro de número de la Academia Chilena de la Historia y es reconocido por sus trabajos sobre las relaciones entre Chile y Estados Unidos. Por su lado, años más tarde, Juan Carlos Estenssoro estudió Historia en la Universidad Católica de Perú, desde una historiografía nueva alejada del positivismo, y optó por centrarse en lo social. Su libro Música y sociedad coloniales, Lima 1680-1830 -al que ya nos hemos referido- se preocupa por problemas como la "forma en que la palabra música es empleada en los textos coloniales" ${ }^{51}$ y trata de "dar sentido global a todas aquellas menciones (breves y dispersas) encontradas en las fuentes”"52, vinculando la música con la sociedad y fijándose en las relaciones de poder en que la sociedad limeña se desenvolvía.

El libro de Pereira Salas es paradigmático por el cuidadoso manejo de las fuentes que hace en juiciosas citas de pie de página, el gran trabajo de archivo que lo sustenta, los datos pormenorizados que ofrece y por su amplitud geográfica y temática (se preocupa tanto por lo profano como por lo religioso). Desde su publicación, este texto es citado con frecuencia y hace parte de la bibliografía de la mayoría de trabajos sobre historia musical, lo cual es entendible no solo por sus aportes sino porque se encuentra en muchas de las bibliotecas latinoamericanas.

50 De acuerdo con Cristián Guerrero Yoacham la obra de Pereira Salas es "El recuento interpretativo y crítico de todas las experiencias humanas del pasado, presentado en un cuadro cronológico integral y ecuménico, concebido en un plano realista, trazado sobre la base de la objetividad de los hechos tal cual las fuentes permiten conocerlos.” Cristian Guerrero Yoacham, "Eugenio Pereira Salas y su obra. A veinte años de su muerte”, Anales de la Universidad de Chile (Santiago), 6, núm. 9 (agosto de 1999). Obtenido en la red mundial el 20 de octubre de 2004, 11:15 horas. http://www.uchile.cl/ publicaciones/anales/9/perfiles.html.

51 Juan Carlos Estenssoro, Música y sociedad coloniales, Lima 1680-1830 (Lima: Colmillo Blanco, 1989), prólogo.

52 Ibídem, 15. 
Otro tipo de documento privilegiado en el estudio de la música colonial es el que reposa en los archivos catedralicios. Comúnmente, lo primero que llamó la atención de los autores fue la existencia actual de partituras en las catedrales de las viejas capitales; en el momento en que tuvieron acceso a los archivos catedralicios también usaron documentación manuscrita, como actas de cabildo y demás papeles referentes al funcionamiento y administración de las iglesias, pues dentro de los datos registrados encontraron menciones a nombramientos de maestros de capilla, pagos de salarios a los músicos, reglamentación de la actividad musical, reparaciones del órgano, compra de partituras y libros de coro, etc.

Los trabajos de los investigadores, fruto de largas jornadas en los archivos catedralicios, son de tres tipos: historias de la música colonial catedralicia, catálogos de las partituras contenidas en cada fondo y trascripción a notación moderna de partituras (publicadas a manera de antologías o recopilando la obra de un compositor). Uno de los mejores representantes del trabajo en archivos eclesiásticos es Robert Stevenson, quien goza de gran reconocimiento en el medio por el grueso de su producción, pues él ha hecho los tres tipos de estudios: artículos y libros sobre música catedralicia de México, Perú, Colombia y Ecuador; catálogos de varios archivos musicales, que recopiló en Renaissance and Baroque Musical Souces in the Americas (1970), y la trascripción y publicación de varias partituras, como las contenidas en su Latin American Colonial Music Anthology (1975). Los trabajos de Robert Stevenson son importantes porque el autor visitó varios países de América Latina -lo cual no se había hecho hasta entonces- y por que su visión de la música colonial no está mediada por los límites políticos actuales, sino que comprende al territorio con la unidad que tuvo durante el imperio español, lo cual también incluye una relación particular con la metrópoli, también estudiada por Stevenson. Es importante decir que este autor tuvo el apoyo de la Unión Panamericana en sus viajes y en la publicación de sus libros ${ }^{53}$.

Podemos separar de los dos tipos de documentación ya enunciados otro más, que por su especificidad ha alimentado a algunos trabajos coloniales. Se trata de las Cartas Annuas de la Compañía de Jesús y los inventarios que se hicieron tras su expulsión del territorio. A través de este tipo de informes se ha podido tener acceso a la actividad musical fuera de las ciudades y se ha vislumbrado qué podía estar sucediendo mientras tanto en las reducciones indígenas, esta vez a cargo de los padres jesuitas.

53 Sería interesante hacer un estudio detallado sobre las políticas culturales de la Unión Panamericana, que no sólo apoyó la labor investigativa de Robert Stevenson sino que entre los años 1957-1973 mantuvo la publicación del Boletín Interamericano de Música / Inter American Music Bulletin (Organization of American States, Department of Cultural Affairs, Pan American Union.) donde se publicó y reseñó la vida musical latinoamericana de este período. Además es el editor de algunas historias de la música y bibliografías como Gilbert Chase, A Guide to the Music of Latin America (2 ${ }^{\mathrm{a}}$ ed. Washington: The Library of Congress and the Pan American Union, 1962); Coopersmith, Music and Musicians, y de un texto de Albert Thomas Luper publicado en 1942 bajo el título The Music of Argentina (Washington: Music Division, Pan American Union, 1942). 
Dentro de los textos que traen referencias a los documentos consultados, encontramos que entre las primeras personas que miraron las Cartas Annuas se encuentra Guillermo Furlong para su libro Músicos argentinos durante la dominación hispánica (1945). Furlong fue sacerdote jesuita, y “conoció al jesuita Pablo Castells, quién puso a su disposición los diez mil documentos copiados por encargo de los jesuitas del Río de la Plata y de Filipinas”54. Después del libro de Furlong pasaron algunos años para que la documentación volviera a ser revisada, y -entre lo que consultamoscreemos que fue precisamente otro padre jesuita quien la volvió a retomar: se trata de Alfred Lemmon y sus investigaciones sobre Guatemala y México ${ }^{55}$. Hoy en día, la música en las misiones de América es un tema bastante prolífico -como ya lo hemos anotado-, y esta documentación, sumada al trabajo etnográfico y material de otros archivos, está sustentando los actuales estudios sobre "música misional”, que es como la han llamado algunos investigadores ${ }^{56}$.

\section{Las partituras}

Otro aspecto importante del tratamiento de las fuentes es el manejo de las partituras, pues, considerando que ellas fueron el medio que se usó durante muchos años para lograr la permanencia en el tiempo del fenómeno sonoro, es entendible que cuando la historia de la música se interesó por la música como tal haya recurrido a este tipo de fuentes. Antes de la llegada de la musicología, la historia de la música colonial incluyó trozos de partituras y en ocasiones sus autores o colaboradores hicieron trascripciones de algunos fragmentos para ilustrar el tema del que hablaban; también era frecuente encontrar textos sin el uso de partituras ni como ilustraciones ni como material pedagógico.

Uno de los primeros autores que se interesó en las partituras como objeto valioso para el conocimiento de la música colonial fue el venezolano Juan Bautista Plaza, quien en 1943 terminó de publicar sus doce cuadernos con trascripción de partituras de compositores venezolanos anteriores y contemporáneos a las guerras de independencia; su trabajo incluye en una primera página una breve biografía de cada compositor y a continuación la trascripción a notación moderna de alguna pequeña obra. Después, en 1952, Jesús Bal y Gay transcribió el Códice del Convento del Carmen; en 1965, Steven Barwick trascribió música de Fernando Franco y, en 1973, Ellie Anne Duque trascri-

54 Ricardo Zavadivker, "Furlong Cardiff, Guillermo”, Diccionario de la música española e hispanoamericana (Madrid), 5 (1999): 292.

55 Véase: Alfred Lemmon, “Jesuit Chroniclers and Historians of Colonial Spanish America: sources for the Ethnomusicologists”, Inter-American Music Review (Los Ángeles), 10, núm. 2 (primavera-verano 1989): 119-129.

56 Sobre el término música misional versaron las ponencias presentadas en el simposio “¿Existe la música misional?” realizado en Santa Cruz de la Sierra (Bolivia) en 1998 y que hasta la fecha se encuentran sin publicar. 
bió obras pertenecientes al archivo de la catedral de Bogotá, de José Cascante. Estos fueron los trabajos sobre partituras anteriores a 1974.

Nuestro balance historiográfico se ha centrado en la producción previa a 1976, cuando llevaba dos años de publicada la Antología de la música colonial en América del Sur de Samuel Claro Valdés. Un año antes, Robert Stevenson publicó su Latin American Colonial Music Anthology y ahora se conocía la trascripción de partituras mexicanas titulada Christmas Music from Baroque México (1974) y la trascripción de la ópera de Tomás de Torrejón y Velasco, La púrpura de la rosa (1976). Después de estas cuatro obras, que demostraron un giro en la manera como se venía haciendo la historia de la música colonial, continuó la producción de trascripciones, y en los años setenta se inició con fuerza la interpretación y grabación de este repertorio, cuando los músicos ya tuvieron material disponible para montar.

Ameritaría un estudio aparte analizar y comparar el repertorio grabado, las trascripciones publicadas y la música detectada en los catálogos de archivos musicales, para poder establecer qué tipo de relación hubo entre estos tres productos de la investigación musicológica ${ }^{57}$. Nosotros hemos visto que la publicación de índices y catálogos de los archivos catedralicios antecede a las trascripciones y grabaciones. Después de indexados los archivos, empezaron a aparecer de manera más frecuente las trascripciones y, un poco más tarde, productores como Roger Wagner se interesan por la interpretación y grabación del repertorio (Wagner grabó música mexicana colonial en 1961), dándole así la bienvenida a otro tipo de preguntas relacionadas con la investigación histórica: ¿cómo sonaba esta música?

Para terminar este artículo, y a manera de epílogo, queremos girar la pregunta que nos hemos hecho en el apartado anterior con relación a las fuentes que se han usado para conocer la música colonial, y convertir este interrogante en una pregunta-espejo: ¿̇irve la música como fuente de conocimiento para la historia colonial?

En 1876, Juan Agustín Guerrero Toro afirmó que “la música es un documento que acredita la verdad de nuestra historia"58. Nosotros seguimos creyendo que lo puede ser, pero consideramos que la información que saquemos de ella está relacionada con el tipo de preguntas que le hagamos y con la capacidad que tengamos de contextualizarla, más que con su naturaleza misma. Ahora nos corresponde demostrarlo o refutarlo en la práctica historiográfica.

57 Un primer acercamiento a la relación entre partituras y grabaciones de música colonial se puede ver en Juliana Pérez González, "La historia de la música colonial y la interpretación del repertorio: un balance historiográfico” en Víctor Rondón, ed., Actas del VEncuentro Científico Simposio Internacional de Musicología, en prensa (Santa Cruz de la Sierra, Bolivia: Asociación Pro Arte y Cultura).

58 Guerrero, La música ecuatoriana, 13. 


\section{BIBLIOTECAS CONSULTADAS}

\section{Argentina:}

Biblioteca de la Universidad de Buenos Aires, Buenos Aires.

Biblioteca del Fondo del Instituto de Investigación Musicológica Carlos Vega, adscrito a la Universidad Católica de Argentina, Buenos Aires.

Biblioteca del Instituto Nacional de Musicología Carlos Vega, Buenos Aires.

Biblioteca Nacional de Argentina, Buenos Aires.

Bibliotecas de la Universidad Católica de Argentina, Buenos Aires.

\section{Colombia:}

Biblioteca de la Academia Superior de Artes de Bogotá (ASAB).

Biblioteca de la Pontificia Universidad Javeriana, Bogotá.

Biblioteca de la Universidad de los Andes, Bogotá.

Biblioteca de la Universidad Nacional de Colombia, Bogotá.

Biblioteca del Instituto Caro y Cuervo, sede Yerbabuena.

Biblioteca del Instituto Colombiano de Antropología e Historia (Icanh), Bogotá.

Biblioteca Luis Ángel Arango, Bogotá.

Biblioteca Nacional, Bogotá.

\section{Chile:}

Biblioteca de la Universidad Católica de Chile, Santiago de Chile.

Biblioteca de la Universidad Católica de Chile: Fondo “Biblioteca del Musicólogo Samuel Claro”, Santiago de Chile.

Biblioteca de la Universidad de Chile, Santiago de Chile.

Biblioteca Nacional de Chile, Santiago de Chile.

\section{Uruguay:}

Biblioteca del Museo Nacional de Uruguay (Museo Romántico): Fondo Biblioteca del Musicólogo Lauro Ayestarán; Hemeroteca, Montevideo.

Biblioteca Nacional de Uruguay, Montevideo.

Biblioteca particular de los musicólogos Coriún Aharonián y Graciela Paraskevais, Montevideo. 


\section{BIBLIOGRAFÍAANALIZADA}

Ayestarán, Lauro. Doménico Zipoli. El gran compositor y organista romano del 1700 en el Río de la Plata. Montevideo: Impresora Uruguaya, 1941.

. "Fuentes para el estudio de la música colonial Uruguaya”. Revista de la Facultad de Humanidades y Ciencias (Montevideo), 1, núm. 1 (1947): 1-57.

. La música en el Uruguay. Montevideo: Servicio Oficial de Difusión Radio Eléctrica (Sodre), 1953.

. Doménico Zipoli, vida y obra. Buenos Aires: Pontificia Universidad Católica Argentina; Facultad de Artes y Ciencias Musicales, 1962.

. “Doménico Zipoli y el barroco musical sudamericano". Revista Musical Chilena (Santiago), 16, núm. 81-82 (julio-diciembre 1962): 94-125.

. "El barroco musical hispanoamericano: los manuscritos de San Felipe Neri (Sucre, Bolivia) existentes en el Museo Histórico Nacional del Uruguay”. Yearbook Inter-American Institute for Musical Research (Nueva Orleans), 1 (1965): 55-93.

Bal y Gay, Jesús. Tesoro de la música polifónica en México. El Códice del convento del Carmen. México: Instituto Nacional de Bellas Artes, 1952.

Bernal Jiménez, Miguel. El archivo musical del Colegio de Santa Rosa de Santa María Valladolid. Morelia: Universidad Michoacana de San Nicolás, 1939.

Boettner, Juan Max. Música y músicos del Paraguay. Asunción: Autores Paraguayos, 1957.

Calcaño, José Antonio. La ciudad y su música. Crónica musical de Caracas. Caracas: Conservatorio Teresa Carreño, 1958.

. "Música colonial venezolana”. Revista Musical Chilena (Santiago), 16, núm. 81-82 (julio-diciembre 1962): 195-200.

Carpentier, Alejo. La música en Cuba. México: Fondo de Cultura Económica, 1946.

Claro, Samuel. "La música en las misiones jesuitas de moxos". Revista Musical Chilena (Santiago), 108 (julio-septiembre 1969): 7-32.

. "La música virreinal en el Nuevo Mundo". Revista Musical Chilena (Santiago) 24, núm. 110 (1970): 7-31. 
. "La música secular de Tomás de Torrejón y Velasco (1644-1728), algunas características de su estilo y notación musical”. Revista Musical Chilena (Santiago), 117 (enero-marzo 1972): 3-23.

- Antología de la música colonial en América del Sur. Santiago: Universidad de Chile, 1974.

. Catálogo del Archivo Musical de la Catedral de Santiago de Chile. Santiago: Instituto de Extensión Musical; Universidad de Chile, 1974.

y Jorge Urrutia Blondel. Historia de la música en Chile. Santiago: Orbe, 1973.

Coopersmith, Jacob M. Music and Musicians of Dominican Republic. Washington: PAU, 1949.

Díaz Gainza, José. Historia musical de Bolivia. 2 ed. 1962; reimpresión. La Paz: Puerta del Sol, 1977.

Díaz, Víctor Miguel. Las bellas artes en Guatemala. Guatemala: Tipografía Nacional, 1934.

Duque, Ellie Anne. José Cascante. Catedral de Bogotá. Archivo musical. Bogotá: Imprenta Distrital, 1973.

Escobar, Luis Antonio. Aspectos de la música colonial colombiana. Bogotá: s. e., 1950.

Estrada, Jesús. Música y músicos de la época virreinal. 2 ed. 1973; reimpresión, México: Diana, 1980.

Furlong, Guillermo. Músicos argentinos durante la dominación hispánica. Buenos Aires: Haurpes, 1945.

García Muñoz, Carmen y Waldemar Axel Roldán. Un archivo musical americano. Buenos Aires: Eudeba, 1972.

Gesualdo, Vicente. Historia de la música en la Argentina. 3 vols. Buenos Aires: Beta S.R.L., 1961.

. "La música en Argentina durante el período colonial”. Revista Musical Chilena (Santiago), 16, núm. 81-82 (julio-diciembre 1962): 125-134.

Grenón, Pedro. Nuestra primera música instrumental: datos históricos. Buenos Aires: Libreria “La Cotizadora Económica”, 1929. [También en Revista de Estudios Musicales (Mendoza) 5 y 6 (1950 y 1951)]. 
Guerrero Toro, Juan Agustín. La música ecuatoriana desde su origen hasta 1875. 2 ed. 1876; reimpresión, Fuentes y documentos para la historia de la música del Ecuador, 1. Quito: Banco Central del Ecuador, 1984 [Primera edición: Quito: Imprenta Nacional, 1876].

Hernández Balaguer, Pablo. "Panorama de la música colonial cubana”. Revista Musical Chilena (Santiago), 16, núm. 81-82 (julio-diciembre 1962): 201-208.

- Catálogo de música de los archivos de la Catedral de Santiago de Cuba y del Museo Bacardí. 2 ed. Santiago de Cuba: Editorial Oriente, 1979 [Primera edición: La Habana: Biblioteca Nacional José Martí, 1961; disponible también en: Hernández Balaguer, Pablo. El más antiguo documento de la música cubana y otros ensayos. La Habana: Letras Cubanas, 1986].

. "La capilla de música en la catedral de Santiago de Cuba”. Revista Musical Chilena (Santiago), 18, núm. 19 (octubre-diciembre 1964): 14-61.

Lange, Francisco Curt. La música eclesiástica en Córdoba durante la dominación hispánica. Córdoba: Universidad Córdoba, 1956.

Luper, Albert Thomas. The Music of Argetina. Washington: Music Division, Pan American Union, 1942.

Martínez Montoya, Andrés. "Reseña histórica sobre la música en Colombia desde la época de la Colonia hasta la fundación de la Academia Nacional de Música”. 2 ed. 1932; reimpresión. Boletín de Programas (Bogotá), 10, núm. 206, (octubre 1961): 1-13 [Primera impresión en: Anuario de la Academia Colombiana de Bellas Artes, 1932].

Moreno, Segundo Luis. "La música en el Ecuador”. El Ecuador en 100 años de independencia. Vol. 2. Quito: Escuela Tipográfica Salesiana; Artes y Oficios, 1930.

. Historia de la música en el Ecuador. Quito: Casa de la Cultura Ecuatoriana, 1972.

Osorio, Juan Crisóstomo. "Breves apuntamientos para la historia de la música en Colombia”. Repertorio Colombiano (Bogotá), 3, núm. 15 (1879): 162-166 [Reimpresión: Textos. Musicología en Colombia: una introducción. Bogotá: Universidad Nacional de Colombia, 2001: 65-82. Se añaden datos del autor].

Pardo Tovar, Andrés. La cultura musical en Colombia. Historia Extensa de Colombia. Vol 10, t. 6. Bogotá: Lerner, 1966. 
Perdomo Escobar, José Ignacio. “Esbozo histórico sobre la música colombiana”. Boletín Latinoamericano de Música (Bogotá), 4 (1938): 387-560.

. Historia de la música en Colombia. Bogotá: Biblioteca Popular de Cultura Colombiana, 1945 [Biblioteca de Historia Nacional. Bogotá: ABC, 1963; edición abreviada. Bogotá: ABC, 1975, y Bogotá: Plaza \& Janés, 1980].

. "Contribución al estudio de la música religiosa en la Conquista y la Colonia”. Boletín de Programas (Bogotá) 20, núm. 205 (septiembre 1961): 1-19.

. "Cultivo de la música y las artesanías en las misiones y reducciones jesuitas en el Nuevo Reino de Granada en la Colonia”. Revista Javeriana (Bogotá), 84, núm. 419 (octubre 1975): 382-385.

. El archivo musical de la catedral de Bogotá. Bogotá: Instituto Caro y Cuervo, 1976.

Pereira Salas, Eugenio. Los orígenes del arte musical en Chile. Santiago: Imprenta Universitaria, 1941.

. Historia de la música en Chile (1850-1900). Santiago: Universidad de Chile, 1957.

Plaza, Juan Bautista. Archivo de música colonial venezolana. 12 vols. Montevideo: Cooperativa Interamericana de Compositores, 1943.

. Música colonial Venezolana. Colección Letras Venezolanas. Caracas: Ministerio de Educación, 1958 [También en: Plaza, Juan Bautista. Temas de música colonial venezolana: biografías análisis y documentación. Caracas: Fundación Vicente Emilio Sojo, 1990].

Plaza, Ramón de la. Ensayos sobre el arte en Venezuela. Facsímil, 1883 reimpresión. Caracas: Imprenta al Vapor de "La Opinión Nacional”, 1983.

Sáenz Poggio, José. "Historia de la música guatemalteca desde la monarquía española hasta fines del año 1877”. 2 ed. Anales de la Sociedad de Geografía e Historia de Guatemala (Guatemala), 22, núm. 1-2 (marzo-junio 1947): 180 [Primera edición: Guatemala: Imprenta la Aurora. 1878. Reeditado como: Historia de la música guatemalteca: desde la monarquía española, hasta fines del año de 1877 / escrita por José Saenz Poggio en el año de 1878. Guatemala: Editorial Cultura, 1997].

Saldívar, Gabriel. Historia de la música en México: épocas precortesiana y colonial. México: Editorial Cultura, 1934. 
Sas, Andrés. "La vida musical en la Catedral de Lima durante la Colonia”. Revista Musical Chilena (Santiago), núm. 81-82, (julio-diciembre 1962): 8-53. . La música en la Catedral de Lima durante el Virreinato. 2 vols. Lima: Universidad Nacional Mayor de San Marcos; Instituto Nacional de Cultura, 1972.

Schianca, Arturo. Historia de la música argentina. Origen y características. Buenos Aires: Establecimiento Gráfico Argentino, 1933.

Spell, Lota M. "Music in the Cathedral of Mexico in the Sixteenth Century". Hispanic American Historical Review (Durham), 26, núm. 3 (agosto 1946): 294-319.

Stevenson, Robert. Music in Mexico. A Historical Survey. Nueva York: Thomas y Crowell, 1952.

. Cathedral Music in Colonial Peru. Lima: Pacific Press, 1959.

. The music of Peru. Aboriginal and Viceroyal Epoch. Washington: Pan American Union, 1960.

. "El archivo musical de Bogotá", trad. Andrés Pardo Tovar. La música colonial en Colombia. Cali: Instituto Popular de Cultura de Cali, 1964 [Traducción de: "The Bogota Music Archive" en Journal of the American Musicological Society, 1962].

. "La música colonial en Colombia”. Revista Musical Chilena. (Santiago), 16, núm. 81-82 (julio-diciembre 1962): 153-171 [También como: “Colonial Music in Colombia”, en The Americas. Academy of American Franciscan History (Berkeley), 19, núm. 2 (octubre 1962): 121-136].

. La música colonial en Colombia, trad. Andrés Pardo Tovar. Cali: Instituto Popular de Cultura de Cali, 1964.

. "La música en la catedral de México: 1600-1750”. Revista Musical Chilena (Santiago), 19, núm. 92 (abril-junio 1965): 11-31 [También como: “Mexico City Cathedral Music: 1600-1750”, en The Americas. Academy of American Franciscan History (Berkeley), 21, núm. 2 (octubre 1964): 111-135].

. "Music in Quito, Four Centuries". Hispanic American Historical Review (Durham), 43, núm. 2 (mayo 1963): 247-266.

. "La música en Quito". Revista Musical Chilena (Santiago), 16, núm. 81-82 (julio-diciembre 1962): 172-194 [También en: Arnahis: Órgano del 
Archivo Nacional de Historia (Quito), 11, núm. 17 (10 de agosto de 1968): 7-28; y en: Colección fuentes y documentos para la historia de la música en el Ecuador. 3 vols. Quito: Banco Central del Ecuador; Centro de Investigación y Cultura, 1989].

. Renaissance and Baroque Musical Sources in the Americas. Washington: OEA, 1970.

. Christmas Music from Baroque Mexico. Berkeley y Los Angeles: University of California, 1974.

. "Latin American Colonial Music Anthology". Inter-American Music Review (Washington), 7 núm. 1 (otoño-invierno 1985): 1-53 [Publicado por Organization of American States, Washington, 1975].

. "Rumbos de la investigación sobre música colonial latinoamericana”. Revista Musical Chilena (Santiago), 134, (abril-septiembre 1976): 3-8 [Publica exactamente el mismo texto como "Tendencias en la investigación de la música colonial”, Heterofonía (México), 9, núm. 4 (julio-agosto 1976): 3-6].

. Torrejón y Velasco, Tomás de. La púrpura de la rosa. Estudio preliminar y transcripción de la música por Robert Stevenson. Lima: Instituto Nacional de Cultura; Biblioteca Nacional, 1976.

. "Mexico City Cathedral Music 1600-1675”. Inter-American Music Review (Los Angeles), 9, núm. 1 (otoño-invierno 1987): 75-113.

Vásquez, Rafael. Historia de la música en Guatemala. Guatemala: Tipografía Nacional, 1950.

Vega, Carlos. La música de un códice colonial del siglo XVII. Buenos Aires: Universidad de Buenos Aires, 1931.

. “Un códice peruano colonial del siglo XVII”. Revista Musical Chilena. (Santiago), 16, núm. 81-82 (julio-diciembre 1962): 54-93.

Villacorta C., J. Antonio. “Índice analítico de la capitanía general de Guatemala”. Anales de la Sociedad de Geografía e Historia de Guatemala (Guatemala), 16, núm. 5 (septiembre 1939): 341-383.

Zapiola, José. Recuerdos de treinta años 1810-1840. 4 ed. [1872]; reimpresión, Santiago: Imprenta de “El Independiente” 1928. 


\section{BIBLIOGRAFÍA CONSULTADA}

Allen, Warren Dwight. Philosophies of Music History. A Study of General Histories of Music. Nueva York: Dover, 1962.

Aretz, Isabel. Síntesis de la etnomusicología en América Latina. Caracas: Monte Ávila, 1980.

. Historia de la etnomusicología en América Latina. Desde la época precolombina hasta nuestros días. Caracas: Fundec; Conac; OEA, 1991.

Behague, Gerard. La música en América Latina. Una introducción. Caracas: Monte Ávila, 1983.

Bergeron, Katherine y Bohlman, Philip, eds. Disciplining Music. Musicology and its Canons. Chicago: University of Chicago, 1992.

Bermúdez, Egberto. "Historia de la música vs. historias de los músicos”. Revista de la Universidad Nacional (Bogotá), 1, núm. 3. (1985): 5-17.

. "Instrumentos musicales latinoamericanos del período colonial. El arpa de Tópaga (Colombia) y la vihuela de la Iglesia de la Compañía de Jesús de Quito (Ecuador)”. Revista Musical de Venezuela (Caracas), 12, núm. 3031, (enero-diciembre1992): 155-162.

. La música en el arte colonial de Colombia. Bogotá: Fundación de Música, 1994.

. "El villancico de navidad: variantes coloniales de una tradición profana y religiosa española”. Revista Credencial Historia (Bogotá), 72 (diciembre 1995): 4-9.

. "La música en las misiones jesuitas en los llanos orientales colombianos, 1725-1810”. Ensayos (Bogotá), 5, núm. 5 (1999): 141-166.

. "Dos que parecen uno: José Cascante padre e hijo. Nuevos documentos”. Memoria. (Bogotá), 8 (2001): 105-111.

Bispo, Alexandre Antonio. "Tendencias e perspectivas da musicologia no Brasil”. Boletin da Sociedade Brasileira de Musicología (Sao Paulo), 1, núm. 1 (1983): 13-51.

Bustos Valderrama, Raquel. "La musicología en Chile”. Revista musical de Venezuela. (Caracas), 9, núm. 25 (mayo-agosto 1988): 143-178. 
Camacho Díaz, Gonzalo. "El arpa en México colonial. Entre lo sacro y lo secular, la transculturación y la mixtura musical”. XXI International Congress. Latin American Studies Association (Chicago, 24-26 de septiembre 1998). Obtenido en la red mundial el 20 de abril de 2004, 09:15 horas. http://168.92.200.17/ gr/libros/lasa98/CamachoDiaz.pdf

Chailley, Jacques. Compendio de musicología. 2 ed. 1958; reimpresión. Colección Alianza Música. Madrid: Alianza Editorial, 1991.

Chase, Gilbert. A Guide to the Music of Latin America. 2 ed. Washington: The Library of Congress; Pan American Union, 1962.

Claro, Samuel. "Hacia una definición del concepto de musicología. Contribución a la musicología hispanoamericana”. Revista Musical Chilena (Santiago), 101 (julio-septiembre 1967): 8-25.

. "Los grandes gestores de la musicología latinoamericana contemporánea”. Revista musical de Venezuela. (Caracas), 12, núm 30-31 (enerodiciembre 1992): 65-81.

Duckles, Vicent y otros. "Historiography”. The New Grove Dictionary of Music and Musicians, ed. Stanley Sadie. Nueva York: MacMillan, 2001. Obtenido en la red mundial el 16 de enero de 2004, 3:30 horas. http:// www.grovemusic.com

. "Musicology". The New Grove Dictionary of Music and Musicians, ed. Stanley Sadie. Nueva York: MacMillan, 2001. Obtenido en la red mundial el 16 de enero de 2004, 4:30 horas. http://www.grovemusic.com

Estenssoro, Juan Carlos. Música y sociedad coloniales, Lima 1680-1830. Lima: Colmillo Blanco, 1989.

Figueroa de Thompson, Annie. Bibliografía anotada sobre la música en Puerto Rico. Barcelona: Instituto de Cultura Puertorriqueña; San Juan de Puerto Rico, 1977.

Godoy, Enrique Alejandro. "Breve semblanza del órgano barroco andino”. Data. Revista del Instituto de Estudios Andinos y Amazónicos (La Paz), 7 (1997): 197-217.

González, Juan Pablo. "Musicología popular en América Latina: síntesis de sus logros, problemas y desafíos”. Revista Musical Chilena (Santiago), 55, núm. 195 (2001): 38-64. 
Grebe, María Ester. “Objeto, método y técnica de investigación en etnomusicología: algunos problemas básicos”. Revista Musical Chilena (Santiago), 133 (1976): 5-27.

Guerrero Yoacham, Cristián. "Eugenio Pereira Salas y su obra. A veinte años de su muerte". Anales de la Universidad de Chile (Santiago), 6, núm. 9 (agosto de 1999). Obtenido en la red mundial el 20 de octubre de 2004, 11:15 horas. http://www.uchile.cl/publicaciones/anales/9/perfiles.html.

Harrison, Frank, Mantle Hood y Claude Palisca. Musicology. New Jersey: PrenticeHall, 1963.

Haskell, Harry. The early music revival: a history. Mineola, Nueva York: Dover, 1996.

Hurtado, Leopoldo. “Apuntes sobre historiografía musical”. Revista Musical Chilena (Santiago), 41 (otoño 1951): 17-36.

Illari, Bernardo. "De los órganos misionales de Chiquitos y su relevancia para la práctica musical”. Resonancias (Santiago), 4 (mayo 1999): 68-81.

. Polychoral Culture: Catedral Music in La Plata (Bolivia), 1680-1730. Tesis de doctorado, Universidad de Chicago, 2001.

Kerman. Joseph. Contemplating Music. Challenges to Musicology. Cambridge: Harvard University, 1985.

Lapique, Zoila. Música colonial cubana. La Habana: Letras Cubanas, 1979.

Lehnhoff, Dieter. "Elementos indígenas y africanos en el villancico guatemalteco del siglo XVI”. Revista Musical de Venezuela (Caracas), 12, núm. 30-31 (enerodiciembre 1992): 203-209.

Lemmon, Alfred. "Jesuit Chroniclers and Historians of Colonial Spanish America: sources for the Ethnomusicologists". Inter-American Music Review (Los Angeles), 10, núm. 2 (primavera-verano 1989): 119-129.

. "Musicología jesuítica en la provincia de Nueva España: el rol de la música”. Revista musical de Venezuela (Caracas), 12, núm. 30-31 (enero-diciembre 1992): 211-223.

Merino, Luis. “Contribución seminal de Robert Stevenson a la musicología histórica del Nuevo Mundo”. Revista Musical Chilena (Santiago), 39, núm. 164 (julio-diciembre 1985): 55-79. 
Miñana Blasco, Carlos. "Entre el folklore y la etnomusicología. 60 años de estudios sobre la música popular tradicional en Colombia”. A contratiempo. Revista de música en la cultura (Bogotá), 11 (2000): 36-49.

Nicrosi Otero, Alfredo. “Lauro Ayestarán. Vida y obra”. Revista Histórica. (Montevideo), 88, núm. 166 (1994): 73-124.

Pascall, Robert. "Style". The New Grove Dictionary of Music and Musicians, ed. Stanley Sadie. Nueva York: MacMillan, 2001. Obtenido en la red mundial el 2 de febrero de 2004, 9:45 horas. http://www.grovemusic.com

Pérez González, Juliana. "La historia de la música colonial y la interpretación del repertorio: un balance historiográfico”. En Víctor Rondón, ed. Actas del V Encuentro Científico Simposio Internacional de Musicología. Santa Cruz de la Sierra (Bolivia): Asociación Pro Arte y Cultura (en prensa).

. Las historias de la música en Hispanoamérica: un balance historiográfico (1876-200). Tesis de licenciatura, Universidad Nacional de Colombia, Bogotá, 2004.

Plaza, Juan Bautista. "La música colonial venezolana al día con la europea”. Revista musical de Venezuela (Caracas), 6, núm. 15-17 (enero-diciembre 1985): 47-53.

Quevedo, Emilio y otros. “La construcción del concepto de fiebre amarilla selvática en Colombia 1906-1948”. Proyecto de investigación, Universidad Nacional de Colombia; Banco de la República; Colciencias, Bogotá, 2003.

Robles Cahero, José Antonio. "Una labor de medio siglo en la investigación musical: Entrevista con Robert Stevenson”. Heterofonía (México), 114-115 (enerodiciembre 1996): 48-63.

Rondón, Víctor. 19 canciones misionales en mapudúngún contenidas en el Chilidúgú (1777) del misionero jesuita, en la Araucaría, Bernardo de Havestadt (1704-1781). Santiago de Chile: Revista Musical Chilena; Fondart, 1997.

ed. Mujeres, negros y niños en la música y sociedad colonial iberoamericana. IV Festival Internacional de Música Renacentista y Barroca Americana "Misiones de Chiquitos". Santa Cruz de la Sierra: Asociación ProArte y Cultura, 2002.

Ruiz, Irma. "Herederos de la colonización jesuítica: el caso de los chiquitos”. Revista musical de Venezuela (Caracas), 16, núm. 34 (mayo-agosto 1997): 7-20. 
. "Dos respuestas al proyecto jesuítico: música y rituales de los chiquitano de Bolivia y de los mbyá de la Argentina”. Música e Investigación (Buenos Aires), 1, núm. 2 (1998): 79-97.

Ruiz, Irma y Gerardo Huseby. "Pervivencia del rabel europeo entre los Mbïá de Misiones (Argentina)”. Temas de Etnomusicología (Buenos Aires), 2 (1986): 67-97.

Saldívar, Gabriel. Bibliografía Mexicana de Musicología y Musicografía. 2 vols. México: INBA, Cenidim, 1992.

Seoane, Carlos y otros. Barroco musical en América Latina. Atelier y seminario del 24 al 29 de febrero. Buenos Aires: Consejo Argentino de la Música [i்1996?].

Stevenson, Robert. Spanish music in the age of Columbus. La Haya: Martinus Nijhoff, 1960.

. Philosophies in American Music History. Washington: Library of Congress, 1970.

. Christmas Music from Baroque Mexico. Berkeley y Los Angeles: University of California, 1974.

Waisman, Leonardo. “Transformaciones y resemantización de la música europea en América: dos ejemplos”. Data. Revista del Instituto de Estudios Andinos y Amazónicos (La Paz), 7 (1997): 197-217.

Zavadivker, Ricardo A. "Furlong Cardiff, Guillermo". Diccionario de la Música Española e Hispanoamericana (Madrid), 5 (1999): 291-292.

Fecha de recepción: 21 de abril de 2004

Fecha de aceptación: 24 de agosto de 2004. 